\title{
ESPECIALIDADES EN EL PROCESO ADMINISTRATIVO ESPAÑOL SOBRE PERSONAL ${ }^{1}$
}

\section{José Bonet NAVARro ${ }^{2}$}

RESUMEN: Estudio de las principales especialidades previstas en el proceso administrativo español en materia de personal. Partiendo de una aproximación al concepto de materia de personal y de la naturaleza jurídica de este proceso como común con especialidades, se analizan las principales cuestiones procesales que plantea el proceso como su adecuación, cuantificación, jurisdicción $y$ competencia. En especial, se estudian las especialidades procesales sean procedentes con independencia del procedimiento adecuado como las previstas para determinados supuestos.

Palabras Clave: Proceso administrativo - Cuestiones de personal Función pública - Procedimiento - Especialidades procesales.

ABSTRACT: This is a study of the eminent domains foreseen in the Spanish administrative procedure concerning personnel. The main procedural issues raised by the proceedings such as its adequacy, quantification, jurisdiction and competence are analyzed, starting from an approximation to the concept of personnel matters and from the juridical nature of this proceeding as being common to eminent domains. Particularly, the procedural specialties are studied either being proceeding independently from the adequate procedural action or those foreseen for given assumptions.

KeY words: Administrative proceeding - Personnel issues - Public duty - Proceeding - Procedural lines.

SUMARIO: I. Introducción. II. Aproximación básica a la materia: "Cuestiones de personal al servicio de las administraciones públicas": 1. La inexistencia de una definición legal suficiente. 2. Doctrina y jurisprudencia más

1 Este trabajo sirvió de base para la conferencia que ofreció el autor en el contexto del "IV Curso de especialización en función pública 2005. Plan de Formación 2005", celebrado en Granada (España), Centro de Estudios Municipales y de Cooperación Internacional-CEMCI, el día 20 de mayo de 2005.

2 Profesor Titular de Derecho Procesal. Universitat de València (Estudi General). Magistrado Suplente de la Audiencia Provincial de Valencia.

Arrículo recibido el 10 de septiembre de 2005. Aprobado por el Comité Editorial el 16 de noviembre de 2005. 
reciente. 3. Insuficiencia del propio concepto "cuestiones de personal". III. Naturaleza de proceso común con especialidades en materia de personal. IV. Procedimiento: adecuación, especialidades aplicables, y cuantificación: 1. Adecuación de procedimiento y competencia de los juzgados de lo contencioso-administrativo (art. 78.1 LJCA). 2. Procedencia de especialidades. 3. Cuantificación. V. Jurisdicción y competencia: 1. Competencia genérica. 2. Competencia objetiva y funcional: A) Juzgados de lo contencioso-administrativo. B) Juzgados Centrales de lo Contencioso-Administrativo. C) Sala de lo Contencioso-Administrativo de los Tribunales Superiores de Justicia. D) Sala de lo Contencioso-Administrativo de la Audiencia Nacional. E) Sala de lo Contencioso-Administrativo del Tribunal Supremo. 3. Competencia territorial. VI. Especialidades procesales en materia de personal con independencia del procedimiento adecuado: 1. Determinación de la cuantía (art. 42.2 LJCA). 2. Prueba (art. 60.3 LJCA). 3. Extensión de los efectos del fallo a quienes no ban sido parte (art. 110 LJCA). VII. Especialidades procesales para las materias de personal en determinados supuestos: 1. Postulación facultativa y designación de domicilio en apelación (arts. 23.3 y 85.3 LJCA). 2. Exclusión del recurso de casación (art. 86.2.a LJCA). Bibliografía citada.

\section{INTRODUCCIÓN}

Los procesos administrativos relativos a "cuestiones de personal" 3 principalmente se tramitarán a través del procedimiento abreviado regulado en el art. 78.1 de la (mal) llamada Ley de la Jurisdicción Contencioso-Administrativa (en adelante LJCA) ${ }^{4}$, aunque también será posible que se sustancien mediante el procedimiento denominado "ordinario".

Tras la reforma que sufrió el citado art. 78 por la Disposición Adicional 14.6 de la LO 19/2003, 23 de diciembre, en su tenor ya no se excepcionan las cuestiones que "se refieran al nacimiento o extinción de la relación de servicio de los funcionarios públicos de carrera”. Sin embargo, a pesar de este cambio de redacción, no puede afirmarse que las cuestiones de personal se conocerán siempre y en todo caso a través

Me refiero a "proceso administrativo" en lugar de otras expresiones más habituales en la literatura jurídica especializada o incluso en el propio derecho positivo, porque resulta reiterativo hablar de proceso "contencioso", "judicial" o "jurisdiccional" cuando el proceso per se ya es todo eso. Otra cosa sería el procedimiento que, ese sí, no es exclusivo del ámbito jurisdiccional.

4 Impropiamente llamada, además de por lo dicho supra, porque resulta en cierto modo equívoco hablar de "jurisdicción" administrativa. La jurisdicción es única, aunque pueda ejercitarse delimitada en este ámbito con especialidades. Por eso la expresión "jurisdicción contencioso-administrativa" ha de entenderse con referencia a las especialidades que la jurisdicción única recibe "en el orden administrativo". 
del procedimiento abreviado puesto que previene que los Juzgados de lo Contencioso-Administrativo "conocen por el procedimiento abreviado de los asuntos de su competencia que se susciten sobre cuestiones de personal al servicio de las Administraciones Públicas", siendo que otros órganos jurisdiccionales distintos a "los juzgados de lo contencioso-administrativo" conocerán de esta materia precisamente mediante el procedimiento ordinario. Igualmente, en la medida que las citadas cuestiones de personal puedan afectar a los derechos fundamentales, alternativamente cabrá que sea adecuado el procedimiento para la protección de los derechos fundamentales de la persona contenido en los arts. 114 a 122 LJCA.

Este trabajo no pretende ofrecer cada uno de los aspectos procedimentales de los procesos en que puedan ventilarse cuestiones de personal, ni siquiera centrándonos en el procedimiento abreviado. Se trataría de una labor inútil e insatisfactoria ya que, dados los estrechos márgenes de un trabajo de esta naturaleza, meramente permitiría mostrar una panorámica superficial e incompleta. Más bien al contrario, únicamente pretendo contribuir al estudio de las especialidades que subsisten en relación con las cuestiones de personal. Y es que, aunque se mantiene buena parte de las previsiones que contenían los arts. 113 a 117 de la anterior LJCA de 1956, en la actualidad solamente cabe hablar de que en materia de personal subsisten especialidades procedimentales para los procesos comunes en los que se ventile la pretensión sobre personal, aunque en algunos casos, como veremos, operen especialmente en el procedimiento abreviado.

\section{Aproximación básica a la idea: "Cuestiones de personal al SERVICIO DE LAS ADMINISTRACIONES PÚBLICAS"}

Posiblemente uno de los problema más arduos en el ámbito de los procesos administrativos que estudiamos sea el de la delimitación del ámbito de aplicación de las especialidades previstas en materia de personal o, en otros términos, conocer el concepto exacto y completo de cuestiones de personal a que se refieren $\operatorname{los} 8.2$,a), 23.3, 78.1 y 86.2 ,a) LJCA. Concepto que integrará el objeto del proceso administrativo 5 , y que nos servirá sobre todo para adecuar el procedimiento y considerar aplicables las especialidades procesales previstas en esta materia.

5 Sobre el mismo, véase PemÁn Gavín, J., "Sobre la nueva regulación de la jurisdicción contencioso-administrativa: las novedades relativas al objeto y las partes y al objeto del proceso", en Revista del Poder Judicial, núm. 54, 1999, pp. 401-48. 


\section{La inexistencia de una definición legal suficiente}

De entrada, puede afirmarse que no contamos con una definición legal suficientemente expresiva de cuestión de personal, siendo además que los vínculos jurídicos que unen a las personas que prestan servicios en las diversas administraciones públicas son múltiples y diversificados, lo que dificulta en cierto modo su delimitación omnicomprensiva.

El punto de partida, y desde luego el eje de las cuestiones de personal en el ámbito administrativo, sin duda es el de funcionario público, sin embargo, ni siquiera sobre el mismo podemos encontrar un concepto legalmente definido en sus contornos. De hecho, el art. 1 de la Ley Articulada de Funcionarios Civiles del Estado (D 315/1964, 7 febrero) ofrece un concepto estricto de funcionario de la Administración pública como "las personas incorporadas a la misma por una relación de servicios profesionales y retribuidos, regulada por el Derecho administrativo". Sin embargo, frente al mismo, aunque sea a efectos penales, el art. 24.2 del vigente Código Penal aprobado por LO 10/1995, 23 noviembre, amplía dicho concepto a "todo el que por disposición inmediata de la ley o por elección o por nombramiento de autoridad competente participe en el ejercicio de funciones públicas".

De otro lado, funcionarios públicos los encontramos fuera de lo que puede considerarse como administración pública en un sentido restrictivo $^{6}$. Y la cuestión se complica si a ello añadimos que junto a los funcionarios públicos presta servicio también personal laboral ${ }^{7}$. En fin, lo bien cierto es que en la legislación se utilizan y manejan conceptos y figuras bien dispares como, además de las citadas, funcionario interino, empleado público, personal eventual, estatutario, militar, personal de

6 Por citar un ejemplo entre muchos, el punto 1.4.2 del Acuerdo Plurianual de 9 de mayo de 2001 para la consolidación del correo público y mejora de las condiciones de trabajo del personal de Correos y Telégrafos, establece mantener "la condición de funcionario, con respeto a los derechos adquiridos, tanto administrativos como retributivos, de acuerdo con su situación de activo o cualquier otra que tuviera reconocida", el "respeto al Régimen de Clases Pasivas del Estado y al Mutualismo Administrativo y al marco de negociación colectiva vigente en la Ley de Organos de Representación (LOR)", así como también la "vinculación de los funcionarios a las normas con rango de Ley de la Función Pública y, complementariamente, desarrollo de un Estatuto Básico del personal funcionario que recoja las especificaciones profesionales de los funcionarios que presten servicios en Correos y Telégrafos. Entre tanto, seguirá vigente el Reglamento de Personal". Así, por citar un ejemplo cercano, el art. 48.1 LO 6/2001, 29 diciembre, de Universidades, prevé que las Comunidades Autónomas "podrán contratar, en régimen laboral, personal docente $e$ investigador entre las figuras siguientes: ayudante, profesor ayudante doctor, profesor colaborador, profesor contratado doctor, profesor asociado y profesor visitante". Y por si ello no fuera suficiente, el mismo art. 48.3 autoriza a las universidades a "contratar para obra o servicio determinado a personal docente, personal investigador, personal técnico u otro personal, para el desarrollo de proyectos concretos de investigación científica o técnica". 
administración y servicios, etc., lo que sin duda dificulta elaborar un concepto de cuestiones de personal a partir de su configuración legal.

\section{Doctrina y jurisprudencia más reciente}

Tampoco la doctrina científica ofrece un concepto definitivo dada su amplitud y diversificación. Con todo, ha de tenerse en cuenta que desde la entrada en vigor de la Constitución española en 1978 la estructura del Estado, en la que se incardinan funcionarios públicos, viene constituida no solamente por el llamado poder ejecutivo, sino que ha de incluir también los llamados órganos constitucionales, como la Corona, Tribunal Constitucional, Cortes Generales, Consejo General del Poder Judicial, etc. ${ }^{8}$.

El art. 1 LJCA ha delimitado los perfiles en este aspecto, cuando se refiere al personal al servicio de la Administración General del Estado, las Administraciones de las Comunidades Autónomas, las Entidades que integran la Administración local, las Entidades de derecho público que sean dependientes o estén vinculadas a las tres anteriores; así como también, la de los órganos competentes del Congreso de los Diputados, del Senado, del Tribunal Constitucional, del Tribunal de Cuentas y del Defensor del Pueblo, así como de las Asambleas Legislativas de las Comunidades Autónomas y de las instituciones autonómicas análogas al Tribunal de Cuentas y al Defensor del Pueblo; Consejo General del Poder Judicial, personal de Juzgados y Tribunales, y hasta de la administración electoral ${ }^{9}$.

En un intento de delimitar el concepto se ha señalado, partiendo de la jurisprudencia, que se trata de "todas las cuestiones derivadas de una relación jurídico-administrativa o estatutaria entre una Administración Pública y su personal, ya se refieran al nacimiento o constitución de la relación jurídica (concursos, oposiciones, nombramientos), a su contenido (derechos económicos, ascensos), situaciones administrativas (excedencias), o extinción, incluso las peticiones de derechos pasivos" ${ }^{10}$.

8 Rosado PACHECO, S., El proceso de personal en la jurisdicción contencioso-administrativa, Marcial Pons, Madrid, 1977, pp. 28-9.

9 Véanse diversos supuestos en Rosado: (n. 8), pp. 31-9.

10 Con referencia a la STS, Sala 3a, 5 sepriembre 1996, TÉllez Aguilera, A., El procedimiento contencioso-administrativo abreviado, Edisofer, Madrid, 2000, p. 82. Por su parte, el ATS, Sala $3^{a}$, Secc. $1^{a}$, 5 febrero 2004, JUR 2004/142571, aclara que "si bien es cierto que, como señala el recurrente, esta Sala ha declarado (así, Autos de 18 de septiembre de 1992, 17 de mayo de 1993, 17 de octubre de 1995 y 24 de noviembre de 1997, entre otros) que son cuestiones de personal al servicio de la Administración Pública las que derivan de la aplicación del régimen de clases pasivas, sin embargo también lo es que, como se ba dicho con reiteración, se trata de cuestiones que no afectan al nacimiento o a la extinción de la relación de servicio y, por lo tanto, están excluidas del acceso al recurso de casación". 
También que la materia de personal es toda aquella que se refiera a cualquier incidencia o vicisitud de los funcionarios públicos respecto de la relación funcionarial, cualquiera que sea la situación del interesado, alcanzando incluso, como ya se ha adelantado, a las pruebas de acceso a tal función y condición y, por supuesto, a todos los derechos ínsitos con el desempeño de la función (por ejemplo los derivados de la promoción, asistencia médica y seguridad social, etc. $)^{11}$. $\mathrm{O}$, en otros términos, que alcanza a todas las vicisitudes derivadas de las relaciones jurídico-administrativas ante una administración pública y su personal, sean funcionarios o no, y comprende tanto las relativas al nacimiento de la relación (procedimientos de selección: concursos y oposiciones), como a su contenido (derechos económicos, haberes, productividad), a las situaciones (excedencia), al puesto de trabajo (clasificación profesional, jornada y horarios, traslados), a las incompatibilidades, a las sanciones, y naturalmente a las materias relacionadas y conexas con el nacimiento y la extinción de la relación, incluidos los derechos pasivos ${ }^{12}$.

Así y todo, conviene distinguir, por su importancia a determinados efectos (y particularmente para el acceso a la casación de la cuestión), por una parte, las cuestiones relativas al nacimiento de la relación funcionarial, planteadas con ocasión del acceso a la condición de funcionario de carrera de quien hasta ese momento no la tenía, incluidos los actos de impugnación de las convocatorias de pruebas y relación de admitidos y aprobados ${ }^{13}$, de modo que no incluye los concursos de traslado $^{14}$ ni los de contratado laboral ${ }^{15}$; y, por otro, las relativas a la extinción,

11 Milans del Bosch y Jordán de Urríes, S., "Órganos y competencias", en Vv. Aa., Jurisdicción contencioso-administrativa (Comentarios a la Ley 29/1998, de 13 de julio, Reguladora de la Jurisdicción Contencioso-Administrativa), (Dirs.: Alnaldo Alcubilla y Fernández Valverde), El Consultor, Madrid, 1998, p. 401.

12 Moreno Catena, V., Derecho Procesal Administrativo, (con otros), Colex, $2^{\mathrm{a}}$ ed., Madrid, 2004, p. 171.

13 Para Sieira Míguez, J. M., "Recurso de casación", en Vv. Aa., Jurisdicción contenciosoadministrativa (Comentarios a la Ley 29/1998, de 13 de julio, Reguladora de la Jurisdicción Contencioso-Administrativa), (Dirs.: Alnaldo Alcubilla y Fernández Valverde), El Consultor, Madrid, 1998, p. 931, el concepto nacimiento incluirá no solamente el acto de nacimiento, sino también la convocatoria de concursos para acceso.

14 Sobre los concursos de traslado, el ATS, Sala $3^{a}$, Secc. $1^{\mathrm{a}}$, 9 diciembre 2002, JUR 2003/96723, deja claro que "como ya ha tenido ocasión de pronunciarse esta Sala, entre otros en Auto de 30 de junio de 2000 recurso $n^{\circ}$ 1346/99 (RJ 2000/5642) "... Los concursos de traslado no son un supuesto de nacimiento de la relación de servicio de funcionarios de carrera, sino que estos procedimientos selectivos están previstos para que participen en ellos quienes precisamente tienen ya tal condición de empleados al servicio de la Administración".

15 Dice el ATS, Sala 3a", Secc. 12, 24 marzo 2000, RJ 2000/2374, "al tratarse de la ejecución de una sentencia que se refiere a la impugnación de un concurso para la contratación de personal laboral, por lo que no afecta al nacimiento de la relación de servicio de un funcionario de carrera, careciendo de virtualidad a los efectos del acceso al recurso de casación los argumentos de la Corporación recurrente acerca del alcance del auto reseñado y la pretendida contradicción con lo resuelto en la sentencia de cuya ejecución se trata". 
respecto de la separación definitiva del servicio cualquiera que sea su causa, como una sanción de separación de servicio, incluida la jubilación, retiro o cualquier otra análoga, y hasta la incompatibilidad y la excedencia voluntaria ${ }^{16}$. En definitiva, cuando la decisión administrativa suponga una auténtica extinción del vínculo funcionarial, quedando fuera las cuestiones relativas al pase a situaciones administrativas del servicio activo, como en los supuestos de incompatibilidades ${ }^{17}$.

Tampoco encontramos ese concepto omnicomprensivo de "cuestión de personal" en la jurisprudencia. La propia diversidad de situaciones ha supuesto que, caso por caso, la jurisprudencia ha venido configurando a golpe sobre todo de sentencia un cuerpo, probablemente no cerrado o incompleto y en cualquier caso abierto a situaciones futuras que en su conjunto representa el concepto cuestiones de personal. Eso sí, no faltan declaraciones genéricas como las que ofrece, entre las más recientes $^{18}$, el ATS (Sala 3 ${ }^{\mathrm{a}}$, Secc. 1 ${ }^{\mathrm{a}}$ ), 24 noviembre 1997 (RJ 1997\8370) cuando manifiesta que la cuestión de personal ${ }^{19}$ es "toda pretensión directamente relacionada con el nacimiento, desarrollo o extinción de la relación de servicio con las Administraciones Públicas (por todos Auto de 25 abril 1995)... Así, la fórmula genérica "cuestiones de personal" comprende todas aquellas incidencias y vicisitudes referidas a los funcionarios públicos respecto a la relación funcionarial (Sentencia del Tribunal Constitucional 35/1990, de 1 marzo...".

Con todo, por muy genéricas que se han presentado, resultan todavía insuficientes ante las nuevas realidades del personal al servicio de la fun-

16 Véase, con referencia a variada jurisprudencia, Téllez: (n. 10), pp. 82-3, notas 149-52.

17 Véase la extensa referencia jurisprudencial que aporta SIEIRA: (n. 13), pp. 929-30. Asimismo, el ATS, Sala 3a , Secc. 1ª 5 febrero 2004, JUR 2004/142571, con ocasión de la recurribilidad en casación dice que "es doctrina reiterada de esta Sala (por todos, Autos de 21 de junio de 1999 y 13 de noviembre de 2000) que la excepción a la imposibilidad de recurrir en casación las resoluciones judiciales que se refieran a cuestiones de personal al servicio de las Administraciones públicas, debe reservarse, en lo que atañe a la extinción de la relación de servicio, para aquellos casos en que es la Administración quien pone fin a la relación de servicio de un funcionario de carrera y se discute por este su procedencia, lo que no ocurre en el caso que nos ocupa, en que lo debatido en la instancia no fue la procedencia de la declaración de inutilidad fisica del recurrente sino las consecuencias y condiciones del apartamiento de la función pública, ya que en el suplico de la demanda se pretendió que se reconociera que la inutilidad física padecida por el recurrente era consecuencia, no de enfermedad común, sino de accidente en acto de servicio, con el derecho a percibir la prestación correspondiente a los derechos pasivos del personal militar. Además, la excepción referida viene circunscrita a las funcionarios de carrera, condición que no tienen los Militares de empleo (Autos de 21 de enero de 2000, 13 de mayo y 18 de octubre de 2002 y 16 de octubre de 2003)".

18 Véase la citadas por GIL IBÁÑ̃Z, J. L., "El nuevo procedimiento contencioso-administrativo abreviado", en Revista del Poder Judicial, núm. 53, 1999, p. 285.

19 SiEIRA: (n. 13), p. 928, trae a colación el Auto de 18 septiembre 1992, que en su opinión es fundamental para concretar que ha de entenderse por cuestión de personal y que se corresponde básicamente con el citado. 
ción pública como es el personal laboral ${ }^{20}$, que, parcialmente al menos, está sometido también a los órganos jurisdiccionales del orden social.

\section{Insuficiencia del propio concepto "cuestiones de personal"}

A los efectos de la adecuación del procedimiento y, además, para conocer si son aplicables las especialidades procesales, resulta ocasionalmente inútil el propio concepto cuestiones de personal puesto que, aunque en principio la materia sobre la que versará la pretensión pueda quedar incluido en su concepto, otros factores excluyen tal adecuación. Así, ha de atenderse ideas como la de impugnación de "disposiciones generales", por cuanto que las especialidades se referían al objeto limitado de "impugnación de actos administrativos", excluyente, por tanto, de la impugnación de las disposiciones de carácter general, lo que se manifiesta en que el art. 23.3 LJCA se refiera a los efectos de postulación, a que la defensa de "sus derechos estatutarios, cuando se refieran a cuestiones de personal que no impliquen separación de empleados públicos inamovibles"21.

\section{NATURALEZA DE PROCESO COMÚN CON ESPECIALIDADES EN MATE- RIA DE PERSONAL}

En mi opinión, puede manifestarse con rotundidad que no existe un verdadero proceso especial en materia de personal. Ahora bien, esta tajante afirmación no supone en absoluto desconocer que la actual LJCA contenga buena parte de las previsiones especiales que se contenían sistemáticamente en los arts. 113 a 117 LJCA 1956, o que en el trámite parlamentario se aludiera al mismo como "procedimiento especial" 22 con

20 Dice la STS, Sala $3^{\text {a }}$, Secc. $1^{\text {a }}, 10$ diciembre 2003. RJ 2003/9527 que: "se trata de actos dictados en materia de personal, en cuanto forman parte de una cadena de actos administrativos que tienen como fin último la enajenación de viviendas militares desocupadas, precisamente en favor de quienes reúnen la condición de militar, o de personal civil, funcionario y laboral, destinado en el Ministerio de Defensa, cualidad esta que no desvirtúa tal calificación, como se tuvo ocasión de precisar en el Auto de 3 de abril de 1997 (citado en la Sentencia de 9 de mayo de 2003 -cuestión de competencia núm. 55/2002- aunque por error material se bablara entonces de sentencia), al señalarse que la condición jurídico-laboral y no funcionarial no es en la doctrina de esta Sala razón excluyente del concepto genérico de cuestiones de personal".

21 Como dice el ATS (Sala 3a, Secc. 7a), 19 junio 2000 (RJ 2000/74444): "debiendo entenderse que tales "cuestiones de personal" hacen referencia a los litigios referidos a la impugnación de actos administrativos que afecten a los derechos estatutarios de los funcionarios, pero no a las impugnaciones de disposiciones generales... sin que se acredite que estemos ante una situación que solo afecte al recurrente, con exclusividad, en su ámbito estatutario".

22 En Boletín Oficial de las Cortes Generales, Congreso de los Diputados, núm. 174, 25 junio 1998, p. 9343, citado por GIL: (n. 18), pp. 278-9. 
indudable falta de precisión técnica. Y no es proceso especial, además de por su desubicación sistemática al no estar incluido en el Título $\mathrm{V}$ de los Procedimientos especiales ${ }^{23}$, porque no se trata más que de especialidades muchas de ellas aplicables con independencia del procedimiento adecuado, salvo pocas excepciones puntuales referidas exclusivamente al abreviado ${ }^{24}$. Además, a esta conclusión llegamos partiendo de una clasificación de procesos que distingue entre los ordinarios o, quizá mejor, comunes, los especiales y, entre unos y otros, los comunes con especialidades. Estos últimos son los que su regulación es especial en algunos aspectos, pero sin que resulte afectada la estructura procedimental, como ocurre con los procesos genuinamente especiales ${ }^{25}$. Y, lo que es más importante, no queda a la discreción de las partes o del juez su adecuación, sino que viene impuesto por normas de ius $\operatorname{cogens}^{26}$.

Como veremos en el punto siguiente, resulta claro que la materia de personal va a ser tramitada en ciertos casos por el llamado procedimiento ordinario, y en la mayoría de ocasiones por el abreviado (art. 78.1 LJCA en relación con los arts. 8 y ss. que regulan la competencia objetiva $)^{27}$. En efecto, la adecuación de procedimiento se realizará en función de que el objeto del proceso verse sobre cuestiones de personal así como en razón del órgano administrativo autor del acto o disposición objeto de "recurso". Y paralelamente, se atribuye competencia objetiva en función de los mismos criterios como se verá más adelante.

Ahora bien, generalmente con independencia del procedimiento base que se siga, se prevén determinadas especialidades en materia de personal que le dotan de cierta sustantividad, aunque sea sin alterar en absoluto la estructura procedimental. Por ello que puede afirmarse, en

23 Por este motivo Sainz Moreno, F., "El procedimiento abreviado", en Vv. AA., Comentarios a la Ley de la Jurisdicción contencioso-administrativa, (Dirs.: Leguina Villa y SÁNCHez Morón), Lex Nova, Valladolid, 1999, p. 364, aunque con alguna prudencia afirma que "tampoco, al menos formalmente es un procedimiento especial".

24 Incluso se ha discutido si el procedimiento abreviado ya es en sí mismo un proceso especial. Sobre este punto, comparto con Moreno: (n. 12), p. 137, que "cabe sostener que el procedimiento abreviado, como cauce general válido para el enjuiciamiento de un conjunto heterogéneo de pretensiones, es uno de los dos procesos ordinarios que la LJCA establece, frente a los procedimientos especiales contenido en el Título V".

25 Para la distinción conceptual, véase Ortells Ramos, M., Derecho Procesal Civil (con otros), Thomson-Aranzadi, 5 ed., Cizur Menor, 2004, pp. 585-8.

26 SAinz: (n. 23), p. 364, recuerda que es así a diferencia de lo que proponía la enmienda del Grupo Parlamentario catalán.

27 El procedimiento abreviado parece que tiene cierta tendencia, sin conseguirlo, a lograr el monopolio de las cuestiones de personal. Garrido Falla, F., Tratado de Derecho Administrativo, III. La justicia administrativa (con otros), Tecnos, Madrid, 2001, p. 263, afirma sobre este procedimiento que su finalidad es agilizar la justicia administrativa, facilitando las causas de escasa cuantía y las cuestiones de personal, esto es, los asuntos más numerosos que penden ante los órganos de la jurisdicción contencioso-administrativa. 
definitiva, que nos encontramos ante un proceso ordinario o común con las especialidades a las que más adelante me referiré y que se refieren a la cuantificación (art. 42.2); postulación (art. 23.3); prueba (art. 60.3); designación de domicilio en recursos (art. 85.3); recurso de casación (art. 86.2.a); o posibilidad de extensión de efectos personas distintas de las partes que se encuentren en situación idéntica cuando concurran las circunstancias del art. 110 todos los preceptos de la LJCA.

En fin, ninguna de las particularidades vistas permiten afirmar que se regule procedimiento especial alguno en materia de personal. Simplemente se contemplan unas previsiones específicas cuando nos encontremos ante tal materia, generalmente con independencia del procedimiento adecuado, aunque con alguna excepción que acerca la especialidad al procedimiento abreviado, como la postulación facultativa en el abreviado, siempre que la cuestión no implique "separación de empleados públicos inamovibles" (arts. 23.3 y 85.3 LJCA), o la exclusión del recurso de casación salvo que se refieran al "nacimiento o a la extinción de la relación de servicio de funcionarios de carrera" (art. 86.2.a) LJCA).

\section{Procedimiento: Adecuación, especialidades aplicables y CUANTIFICACIÓN}

1. Adecuación de procedimiento y competencia de los juzgados de lo contencioso-administrativo (art. 78.1 LJCA)

La adecuación de procedimiento habrá de hacerse paralelamente a la determinación de la competencia objetiva de los juzgados de lo contencioso-administrativo. Partiendo de que nos encontramos ante una cuestión de personal en los términos vistos, a pesar de la reforma operada por la Disposición Adicional 14.6 de Ley Orgánica 19/2003, de 23 diciembre, por la que se modifica la redacción del art. 78.1 LJCA y parece excluirlo, lo bien cierto es que la adecuación de procedimiento requiere partir de la determinación de la competencia de estos juzgados puesto que el abreviado será el procedente siempre que se den las previsiones del art. 78.1 LJCA, esto es, cuando la competencia corresponda a los Juzgados de lo Contencioso-Administrativo de los asuntos de su competencia (así como, quizá, incluyendo a los Juzgados centrales de lo Contencioso-administrativo). Actualmente el tenor literal del precepto ha quedado como sigue $^{28}$ : "Los Juzgados de lo Contencioso-Administrativo de este Orden Juris-

28 El art. 78.1 LJCA anterior a la LO 19/2003 disponía que "los recursos que se deduzcan en las materias de que conozcan los Juzgados de lo Contencioso-administrativo, cuando su cuantía no 
diccional conocen por el procedimiento abreviado de los asuntos de su competencia que se susciten sobre cuestiones de personal al servicio de las Administraciones Públicas, sobre extranjería y sobre inadmisión de peticiones de asilo político, así como todas aquellas cuya cuantía no supere los 13.000 euros".

Respecto de la anterior redacción, el cambio ha sido sustancial en ciertos aspectos como el aumento porcentual de la cuantía que ha aumentado en más de un $400 \%$. Y lo mismo parece ocurrir en relación con el procedimiento adecuado puesto que aparentemente se elimina la referencia a que el procedimiento abreviado será improcedente respecto de aquellas cuestiones de personal referidas "al nacimiento o extinción de la relación de servicio de los funcionarios públicos de carrera". Sin embargo, a pesar del cambio de redacción, la excepción se mantiene en realidad ya que en la actualidad, además de tratarse de cuestiones de personal, han de ser conocidas por los juzgados de lo contencioso-administrativo en los "asuntos de su competencia", y las referidas al nacimiento o extinción de la relación de servicios de funcionarios de carrera son competencia de los Tribunales Superiores de Justicia en virtud de lo previsto en los arts. 8.2.a) y 10.1.a) LJCA.

Una duda importante se plantea en relación a si la expresión del citado art. 78.1 LJCA, cuando se refiere a "los Juzgados de lo Contencioso-Administrativo de este Orden Jurisdiccional" incluye o no a los juzgados centrales de lo contencioso-administrativo. Sobre esta cuestión existe disparidad de opiniones. Para algunos autores, sobre todo partiendo del tenor literal del precepto, el procedimiento abreviado queda vedado para los juzgados centrales ${ }^{29}$, para otros, en cambio, resulta obvio que habría que incluirlos ${ }^{30}$. TÉLlez AgUiLERA ${ }^{31}$ aporta los siguientes argumentos para su inclusión: $1 .^{\circ}$ Porque la voluntad de la ley es atribuir el procedimiento abreviado a órganos unipersonales, con la única excepción del art. 29.2 LJCA. 2. ${ }^{\circ}$ Las limitaciones introducidas en el Senado se orientaron a limitar las materias a tramitar a través del procedimiento abreviado, reservando el mismo a asuntos de pequeña cuantía pero importantes en número. $3 .^{\circ}$ Lo contrario traería importantes situaciones discriminantes.

supere las 500.000 pesetas o se trate de cuestiones de personal que no se refieran al nacimiento o extinción de la relación de servicio de los funcionarios públicos de carrera, se sustanciarán por el procedimiento abreviado regulado en este artículo".

29 Véanse los autores que cita Téllez: (n. 10), pp. 72-3, nota 122.

30 Para Garrido: (n. 27), p. 264, "es obvio que también los Juzgados Centrales de lo Contencioso-administrativo aplicarán el procedimiento abreviado, aunque no se refiera a ellos expresamente el artículo 78 de la LJCA". Por su parte, GIL: (n. 18), pp. 279-81, estima que a pesar de que en el trámite parlamentario se limitó el ámbito de aplicación de este procedimiento, son mayores y más principales los argumentos que abonan una interpretación extensiva de la expresión "Juzgados de lo Contencioso-Administrativo".

31 TÉLlez: (n. 10), pp. 73-4. 
En efecto, lo que parece claro es que si los juzgados centrales son ajenos a la previsión del art. 78.1 LJCA, además de desentenderse de los debates parlamentarios en su tramitación, supondrá dar un tratamiento dispar cuando no discriminatorio entre funcionarios públicos, según hayan sido o no trasferidos a una comunidad autónoma ${ }^{32}$.

Con todo, se da tratamiento dispar respecto de los "recursos" interpuestos por los funcionarios militares en materia de ascensos, orden y antigüedad en el escalafón y destinos, que seguirán los trámites del juicio ordinario dado que la competencia para su conocimiento corresponderá a la Sala de lo Contencioso-Administrativo de la Audiencia Nacional ${ }^{33}$. Tratamiento dispar que, en todo caso, se da igualmente respecto de las cuestiones personal relativas al nacimiento y extinción de la condición de funcionario público que, por estar atribuida su competencia a la Sala de lo Contencioso-Administrativo de los Tribunales Superiores de Justicia (art. 8.2.a) y 10.1.a) LJCA), y de la Audiencia Nacional en única instancia (art. 11.1.a) LJCA), supone la ausencia de doble instancia procesal ${ }^{34}$.

En realidad, esta ausencia de doble instancia procesal tiene en $\mathrm{mi}$ opinión una importancia relativa. En primer lugar, porque no existe un derecho a una doble instancia en el ámbito del derecho procesal administrativo ni siquiera tampoco un derecho al recurso en dicho ámbito. La única referencia al mismo la encontramos en el art. 14.5 del Pacto Internacional de Derechos Civiles y Políticos por el que "toda persona declarada culpable de un delito tendrá derecho a que el fallo condenatorio y la pena que se le haya impuesto sean sometidos a un tribunal superior, conforme a lo prescrito por la ley" y parece claro que no lo recoge en este ámbito. Además, ha de añadirse que el hecho de que conozcan órganos colegiados y superiores compensa en cierto modo la existencia de recursos extraordinarios frente a sus resoluciones o incluso la inexistencia de todo recurso, lo que se explica por las mayores garantías que implica el enjuiciamiento por órgano colegiado. Además, una doble instancia real no es posible en ningún caso, ni siquiera con la apelación siendo siempre limitada su eficacia práctica para el control fáctico y de valoración de la prueba de la resolución apelada. Otra cosa es que en la medida que la apelación suponga mayores garantías, desde un punto de vista de política legislativa podamos estar de acuerdo, siempre que se asuman los costes y "desbarajustes orgánicos" que ello

32 Aunque entiende que no habría que incluirlos, en ese sentido también Ruiz Risueño, F., El proceso contencioso-administrativo. Ley 29/1998, de 13 de julio, Reguladora de la Jurisdicción Contencioso-Administrativa, Colex, 5a ed,, Madrid, 2004, p. 263, nota 12.

33 Como indica, con razón, GIL: (n. 18), pp. 285-6, resulta un contrasentido aparte de no estar suficientemente claros los motivos de aquella atribución competencial.

Ruiz: (n. 32), pp. 171-2. 
implica, en que se instaure un recurso de apelación general. Lo que, a poco que se medite, resultará a todas luces inviable en muchas ocasiones, al menos cuando conozca el Tribunal Supremo en primera instancia (art. 12.1 LJCA).

De otro lado, ha de notarse que el procedimiento abreviado no es siempre y en todo caso equivalente a órgano jurisdiccional unipersonal a pesar de la dicción del art. 78 LJCA. Al menos en un supuesto concreto conocerán órganos colegiados, concretamente cuando se formule "recurso" basado en que la administración no ejecuta sus propios actos. Así, en atención al art. 29.2 LJCA $^{35}$, si por la autoridad administrativa correspondiera la competencia a órgano jurisdiccional colegiado, habría de seguirse siempre el procedimiento abreviado ${ }^{36}$.

\section{Procedencia de especialidades}

Una vez adecuado el procedimiento, en atención a la materia de personal que nos ocupa y con independencia del mismo, serán en su caso de aplicación matizadamente las especialidades legalmente previstas para la misma.

En cualquier caso, tratándose de materia de personal, la cuantía se reputará indeterminada por el mero hecho de que la pretensión se refiera a los funcionarios públicos y no verse sobre derechos o sanciones susceptibles de valoración económica (art. 42.2 LJCA). Por otra parte, en el caso de que se trate de sanción disciplinaria, en tanto en cuanto pueda suponer o no la extinción de la relación de servicio del funcionario de carrera, se recibirá siempre el proceso a prueba cuando exista disconformidad en los hechos. También cabrá la extensión de efectos a personas distintas de las partes con independencia del procedimiento cuando se den las circunstancias del art. 110 LJCA.

Otras especialidades, sin embargo, serán matizadamente aplicables a ciertos supuestos y que de algún modo vienen a coincidir con los que con anterioridad a la reforma se tramitaban por el procedimiento abreviado. Así, la postulación facultativa de los funcionarios que podrán comparecer por sí mismos en defensa de sus derechos estatutarios, solamente será admisible cuando implique separación de empleados públicos inamovibles (art. 23.3 LJCA). Por ello mismo que la designación de domicilio en recursos a que se refiere el art. 85.3 LJCA solamente

35 Dispone el art. 29.2 LJCA que: "Cuando la Administración no ejecute sus actos firmes podrán los afectados solicitar su ejecución, y si esta no se produce en el plazo de un mes desde tal petición, podrán los solicitantes formular recurso contencioso-administrativo, que se tramitará por el procedimiento abreviado regulado en el artículo $78^{\prime \prime}$.

MORENO: (n. 12), p. 137. 
procederá cuando el procedimiento en instancia sea a los que se refiere el art. 23.3 LJCA. Por último, a efecto de recurso de casación, es claro que la exclusión del mismo se centra en las materia de personal que no "afecten al nacimiento o a la extinción de la relación de servicio de funcionarios de carrera” (art. 86.2.a) LJCA).

\section{Cuantificación}

La cuantificación del procedimiento tiene indudable interés para las partes, puesto que el mismo tendrá importantes consecuencias sobre todo en orden a la admisibilidad de los recursos: a) Apelación: no será admisible cuando la cuantía no exceda del equivalente en euros a tres millones de pesetas (art. 81.1.a LJCA). b) Casación: no será admisible si no supera veinticinco millones de pesetas (art. 86.2,b) LJCA). c) Casación para unificación de doctrina: no será recurrible si no supera tres millones de pesetas (arts. 96.3 y 99.2 LJCA). Si bien también tendrá relevancia a otros efectos también de suma importancia, como lo es la cuantificación de las costas que serán reguladas y tasadas según lo dispuesto en la LEC (art. 139.6 LJCA), que remite, entre otros, al art. 394.3 LEC en cuanto prevé que el litigante vencido solamente estará obligado a pagar, de la parte que corresponde a abogados y demás profesionales que no estén sujetos a tarifa o arancel, "una cantidad total que no exceda de la tercera parte de la cuantía del proceso... las pretensiones inestimables se valorarán en tres millones de pesetas"; mismo límite que se prevé a los efectos de imposición de multas por incumplimiento del respeto a las reglas de la buena fe procesal, que podrá oscilar de 180 a 6.000 euros, "sin que en ningún caso pueda superar la tercera parte de la cuantía del litigio” (art. 247.3 LEC).

A diferencia de lo previsto en el art. 253 LEC, no será imprescindible que figure la expresión de la cuantía en la demanda, sino que esta será fijada por el órgano jurisdiccional una vez formulados los escritos de demanda y contestación, en los que las partes podrán exponer, por medio de otrosí, su parecer al respecto, sin perjuicio de que, en caso contrario, el órgano jurisdiccional requiera al demandante para su fijación o su fijación judicial mediante auto irrecurrible, sin perjuicio del correspondiente recurso de queja por inadmisión de recursos (art. 40 LJCA).

La regla general es que la cuantía se determinará por el valor de la pretensión o pretensiones acumuladas o ampliadas, si bien "no comunicará a las de cuantía inferior la posibilidad de casación o apelación"; y si existiese varios demandantes "se atenderá al valor económico de la pretensión deducida por cada uno de ellos, y no a la suma de todos" (art. 41.2 LJCA). En cambio, las reglas generales de cuantificación vienen previstas en los arts. 251 y 252 LEC, si bien con las especialidades del art. 42 LJCA, esto es: 
a) Cuando el demandante solicite solamente la anulación del acto, se atenderá al contenido económico del mismo, para lo cual se tendrá en cuenta el débito principal, pero no los recargos, las costas ni cualquier otra clase de responsabilidad, salvo que cualquiera de estos fuera de importe superior a aquel.

b) Cuando el demandante solicite, además de la anulación, el reconocimiento de una situación jurídica individualizada, o cuando solicite el cumplimiento de una obligación administrativa, la cuantía vendrá determinada:

Primero. Por el valor económico total del objeto de la reclamación, si la Administración pública hubiere denegado totalmente, en vía administrativa, las pretensiones del demandante.

Segundo. Por la diferencia de la cuantía entre el objeto de la reclamación y el del acto que motivó el recurso, si la Administración hubiera reconocido parcialmente, en vía administrativa, las pretensiones del demandante.

Por último se reputarán de cuantía indeterminada "los recursos dirigidos a impugnar directamente las disposiciones generales, incluidos los instrumentos normativos de planeamiento urbanístico, los que se refieran a los funcionarios públicos cuando no versen sobre derechos o sanciones susceptibles de valoración económica, así como aquellos en los que junto a pretensiones valuables económicamente se acumulen otras no susceptibles de tal valoración".

Esta última previsión tiene gran relevancia por lo que ahora nos interese. Siendo la materia de personal indeterminada, lo que será habitual por no versar sobre derechos o sanciones susceptibles de valoración económica, impedirá los recursos en tanto en cuanto su admisibilidad dependa de alcanzar determinada cuantía (arts. 81.1.a ${ }^{37}, 96.3$ y 99.2 LJCA). Y en materia de condena en costas habrán de valorarse en el equivalente en euros a tres millones de pesetas. Valoración que, aunque no directamente aplicable en materia de sanciones, en la práctica es la que se impone, puesto que para la imposición de multas por incumplimiento del respeto a las reglas de la buena fe procesal, la sanción podrá oscilar de ciento o ochenta a seis mil euros, "sin que en ningún caso pueda superar la tercera parte de la cuantía del litigio" (art. 247.3 LEC), y si seis mil euros es el máximo y ha de ser una tercera parte, se está partiendo al final de una valoración cuantitativa de dieciocho

37 Por eso que GARRIDo: (n. 27), p. 266, afirme que como regla general, las "cuestiones de personal" son resueltas en única instancia por órganos judiciales unipersonales en el marco del procedimiento abreviado. 
mil euros, esto es, es equivalente en euros, debidamente redondeados, a tres millones de pesetas. En cualquier caso, la imposición de sanciones es una práctica poco habitual en los órganos jurisdiccionales civiles y es de prever que, al menos por el momento, todavía vaya a serlo menos en los del orden administrativo.

\section{Competencia}

\section{Competencia genérica}

La competencia genérica, esto es, la distribución de la jurisdicción entre los distintos órdenes viene atribuida a los órganos jurisdiccionales administrativos por los arts. 1, 2, 4 LJCA y 9.4 LOPJ en sentido positivo, y en sentido negativo por las cuestiones atribuidas expresamente a otros órdenes, a la jurisdicción militar y a la "jurisdicción" de conflictos o a la decisión del superior jerárquico administrativo.

Posiblemente la determinación más problemática de competencia genérica se dé en relación con los órganos jurisdiccionales del orden social. Partiendo de la redacción del art. 9.4 y 5 LOPJ $^{38}$, puede afirmarse, en definitiva, que el personal al servicio de la Administración vinculado por relación laboral determinará el orden jurisdiccional competente. El problema así se limita a la determinación del concepto "funcionario público". Si bien resulta más problemática la distinción en los supuestos de intervención administrativa en las relaciones laborales y de actuación de la Administración de la Seguridad Social ${ }^{39}$.

38 Dispone que "4. Los del orden contencioso-administrativo conocerán de las pretensiones que se deduzcan en relación con la actuación de las Administraciones públicas sujeta al derecho administrativo, con las disposiciones generales de rango inferior a la Ley y con los Reales Decretos Legislativos en los términos previstos en el artículo 82.6 de la Constitución, de conformidad con lo que establezca la Ley de esa jurisdicción. También conocerán de los recursos contra la inactividad de la Administración y contra sus actuaciones materiales que constituyan vía de becho. Conocerán, asimismo, de las pretensiones que se deduzcan en relación con la responsabilidad patrimonial de las Administraciones públicas y del personal a su servicio, cualquiera que sea la naturaleza de la actividad o el tipo de relación de que se derive. Si a la producción del daño bubieran concurrido sujetos privados, el demandante deducirá también frente a ellos su pretensión ante este orden jurisdiccional. Igualmente conocerán de las reclamaciones de responsabilidad cuando el interesado accione directamente contra la aseguradora de la Administración, junto a la Administración respectiva. También será competente este orden jurisdiccional si las demandas de responsabilidad patrimonial se dirigen, además, contra las personas o entidades públicas o privadas indirectamente responsables de aquellas. 5. Los del orden jurisdiccional social conocerán de las pretensiones que se promuevan dentro de la rama social del Derecho, tanto en conflictos individuales como colectivos, así como las reclamaciones en materia de Seguridad Social o contra el Estado cuando le atribuya responsabilidad la legislación laboral".

39 Cordón Moreno, F., El proceso Contencioso Administrativo, Aranzadi, Pamplona, 1999, Pp. 53-8. 
Asimismo, interesa destacar que, partiendo del tenor del art. 3.1 del Texto Refundido de la Ley de Procedimiento Laboral ${ }^{40}$, resulta patente que se trasladan al orden social las pretensiones relativas al ejercicio de la potestad sancionadora por infracciones, con la única excepción de las que imponga la Tesorería de la Seguridad Social o entidades gestoras, así como las resoluciones administrativas relativas a la regulación de empleo y actuaciones administrativas en materia de traslados colectivos. No se menciona al personal estatutario de la Seguridad Social, ahora bien, dado que la Disposición derogatoria del RDLeg declara expresamente la vigencia del art. 45 D 2065/1974, 30 mayo, el personal de las instituciones sanitarias de la Seguridad Social sigue sometido a los tribunales del orden social ${ }^{41}$.

De otro lado, el art. 3.b) LJCA excluye de su ámbito el "recurso contencioso-disciplinario militar", que se regula en los arts. 448 y 518 LO 2/1989, 13 abril, Procesal Militar.

La competencia genérica, o por órdenes jurisdiccionales, podrá ser apreciada en cualquier momento (art. 9.6 LOPJ y 5 LJCA), con indicación del orden que corresponda, y con la previsión al respecto del art. 5.3 LJCA.

\section{Competencia objetiva y funcional}

Sin perjuicio de que estos órganos jurisdiccionales puedan tener competencia en otros ámbitos, por lo que ahora interesa, tienen competencia objetiva y funcional en los siguientes aspectos:

40 Tras varias modificaciones, por fin dispone que: "1. No conocerán los Órganos Jurisdiccionales del Orden Social: a) De la tutela de los derechos de libertad sindical y del derecho a buelga relativa a los funcionarios públicos y al personal al que se refiere el artículo 1.3 a) del Texto Refundido de la Ley del Estatuto de los Trabajadores. b) De las resoluciones y actos dictados en materia de inscripción de empresas, formalización de la protección frente a riesgos profesionales, tarifación, cobertura de la prestación de incapacidad temporal, afiliación, alta, baja y variaciones de datos de trabajadores, así como en materia de liquidación y gestión recaudatoria y demás actos administrativos distintos de los de la gestión de prestaciones de la Seguridad Social. Asimismo, quedan excluidas de su conocimiento las resoluciones en materia de gestión recaudatoria dictadas por su respectiva entidad gestora en el supuesto de cuotas de recaudación conjunta con las cuotas de Seguridad Social, así como las relativas a las actas de liquidación y de infracción. c) De las pretensiones que versen sobre la impugnación de las disposiciones generales y actos de las Administraciones Públicas sujetos al Derecho Administrativo en materia laboral, salvo los que se expresen en el apartado siguiente (...) 2. Los Organos Jurisdiccionales del Orden Social conocerán de las pretensiones sobre: a) Las resoluciones administrativas relativas a la imposición de cualesquiera sanciones por todo tipo de infracciones de orden social, con las excepciones previstas en la letra b) del apartado 1 de este artículo. b) Las resoluciones administrativas relativas a regulación de empleo y actuación administrativa en materia de traslados colectivos".

41 FernÁndez VAlverde, F., "Del orden jurisdiccional contencioso-administrativo", en Vv. AA., Jurisdicción contencioso-administrativa (Comentarios a la Ley 29/1998, de 13 de julio, Reguladora de la Jurisdicción Contencioso-Administrativa), (Dirs.: Alnaldo Alcubilla y Fernández VAlverde), El Consultor, Madrid, 1998, pp. 376-7. 


\section{A) Juzgados de lo contencioso-administrativo}

Los Juzgados de lo Contencioso-administrativo, que son órganos unipersonales y de ámbito provincial sin perjuicio de que puedan existir creados por ley con ámbitos inferiores o superiores a la provincia dentro de una misma comunidad autónoma ${ }^{42}$, serán competentes con carácter general para conocer en "única o primera instancia... de los recursos que se deduzcan frente a los actos de las entidades locales o de las entidades y corporaciones dependientes o vinculadas a las mismas..." (art. 8.1 LJCA), entre las que se incluyen las materias de personal; así como también de los actos de las Comunidades autónomas, que no procedan del respectivo consejo de Gobierno, también en materia de personal pero siempre que no se refieran al nacimiento o extinción de la relación de servicio de funcionarios de carrera, cuya competencia corresponderá a órgano colegiado, esto es, a los Tribunales Superiores de Justicia (arts. 8.2.a) y 10.1 a) LJCA) ${ }^{43}$.

\section{B) Juzgados Centrales de lo Contencioso-Administrativo}

Se trata de órganos también unipersonales cuyo ámbito se extiende a toda España. Conocerán en primer o única instancia de los actos dictados por Ministros y Secretarios de Estado (o por quienes ejerciten competencias delegadas de estos) en materia de personal con las siguientes excepciones:

- Que se refieran al nacimiento o extinción de la relación de servicio de funcionarios de carrera, cuya competencia corresponde a órgano colegiado, esto es, a la Sala de lo Contencioso-Administrativo de la Audiencia Nacional (art. 11.1.a LJCA), con la misma lógica que el personal autonómico o local sobre nacimiento o extinción de la relación de servicio se atribuye al TSJ correspondiente.

42 Véase Sala Sánchez, P., Derecho Procesal Administrativo (con otros), Colex, 2a ed., Madrid, 2004, pp. 22-5.

43 Igualmente, en cuanto puedan referirse a materias de personal, el mismo art. 8.3 LJCA dispone que: "3. Conocerán en única o primera instancia de los recursos que se deduzcan frente a disposiciones y actos de la Administración periférica del Estado y de las Comunidades Autónomas, contra los actos de los organismos, entes, entidades o corporaciones de derecho público, cuya competencia no se extienda a todo el territorio nacional y contra las resoluciones de los órganos superiores cuando confirmen íntegramente los dictados por aquellos en vía de recurso, fiscalización o tutela. Se exceptúan los actos de cuantía superior a 60.000 euros dictados por la Administración periférica del Estado y los organismos públicos estatales cuya competencia no se extienda a todo el territorio nacional, o cuando se dicten en ejercicio de sus competencias sobre dominio público, obras públicas del Estado, expropiación forzosa y propiedades especiales". 
- Actos de cualesquiera órganos centrales del Ministerio de Defensa referidos a ascensos, orden y antigüedad en el escalafonamiento y destinos, cuya competencia corresponde igualmente a la Sala de lo Contencioso-Administrativo de la Audiencia Nacional (arts. 9.a y 11.1.a LJCA) $)^{44}$.

- Cuestiones de personal que, a pesar de ser resueltas por ministro o secretario de Estado, confirmen en vía de recurso, fiscalización o tutela, actos dictados por órganos inferiores (art. 9. a LJCA). Por ello que si conocerán los juzgados centrales cuando rectifiquen la resolución que en "alzada" les hubiera llegado, tanto en sentido peyorativo como más beneficioso ${ }^{45}$.

Igualmente, en cuanto puedan afectar a materia de personal, en virtud del art. 9.c) LJCA también serán competentes para conocer de recursos contra "las disposiciones generales y contra los actos emanados de los organismos públicos con personalidad jurídica propia y entidades pertenecientes al sector público estatal con competencia en todo el territorio nacional, sin perjuicio de lo dispuesto en el párrafo i) del apartado 1 del artículo 10".

Como se observa, cuando las cuestiones de personal se refieran al nacimiento y extinción de la condición de funcionario público, la competencia se atribuye a órgano colegiado, según los casos al TSJ o a la AN. Esta lógica coadyuva a concluir, en mi opinión, a estimar que cuando el art. 78.1 LJCA habla de juzgados de lo contencioso-administrativo no excluye a los juzgados centrales. Asimismo, por otra parte, en las materias más importantes por afectar al nacimiento o extinción de la condición de funcionario público, se priva de doble instancia por venir atribuida la competencia a dichos órganos colegiados. No obstante, como se advirtió supra, me parece irrelevante este diferente tratamiento.

\section{C) Sala de lo Contencioso-Administrativo de los Tribunales Supe- riores de Justicia}

El Tribunal Superior de Justicia es un órgano colegiado, con ámbito territorial de Comunidad autónoma, y tiene competencia objetiva y funcional.

\footnotetext{
44 Entre las críticas a esta previsión, indica Milans: (n. 11), p. 413, que no se entiende por qué no se residencia en el juzgado central, que conoce de autoridades superiores, y considera que es un desperdicio para la justicia que la discusión del puesto escalafonal exija que un órgano colegiado, integrado por cinco magistrados, tenga que conocer de la pretensión.

45 RuIZ: (n. 32), p. 414.
} 


\section{a) Competencia objetiva}

Destaca que tendrán competencia residual sobre aquellas cuestiones no atribuidas a otros órganos jurisdiccionales del orden administrativo (art. 10.1.j LJCA), así como, en particular de los actos de la Entidades locales y de las Comunidades autónomas cuyo conocimiento no se atribuya a los juzgados de lo contencioso-administrativo (art. 10.1.a LJCA).

Asimismo, conocerá de los "actos y resoluciones dictados por órganos de la Administración General del Estado cuya competencia se extienda a todo el territorio nacional y cuyo nivel orgánico sea inferior al de Ministro o Secretario de Estado en materias de personal, propiedades especiales y expropiación forzosa" (art. 10.i LJCA). Ha de indicarse que cuando la materia de personal se refiera al nacimiento o extinción de la relación de servicios de funcionarios de carrera, no basta con su conocimiento a órgano colegiado como el TSJ sino que se atribuye su competencia a la Sala de lo contencioso-administrativo de la AN (art. 11.1.a LJCA) ${ }^{46}$.

\section{b) Competencia funcional}

Conocerán en segunda instancia del recurso de apelación contra sentencias y autos de los juzgados de lo contencioso-administrativo; así como de los correspondientes recursos de queja (art. 10.2 LJCA). Igualmente conocerán de los mal llamados "recursos de revisión" 47 contra las sentencias firmes de los juzgados de lo contencioso-administrativo; así como del recurso de casación para la unificación de doctrina y en interés de ley (art. 10.3.5. y 6 LJCA).

\section{D) Sala de lo Contencioso-Administrativo de la Audiencia Nacional}

La Audiencia Nacional es órgano colegiado también y con ámbito territorial que se extiende a todo el territorio español.

46 Además de lo anterior, en cuanto puedan referirse a materia de personal, también conocerán de las materias a las que se refiere el art. $10 \mathrm{LJCA}$, esto es, disposiciones generales emanadas de las Comunidades Autónomas y de las Entidades locales; c) Los actos y disposiciones de los órganos de gobierno de las asambleas legislativas de las Comunidades Autónomas, y de las instituciones autonómicas análogas al Tribunal de Cuentas y al Defensor del Pueblo, en materia de personal, administración y gestión patrimonial. (...) y g) Los convenios entre Administraciones públicas cuyas competencias se ejerzan en el ámbito territorial de la correspondiente Comunidad Autónoma.

47 La revisión no es un recurso, sino un procedimiento autónomo porque procede frente a resolución firme y esta no existe mientras quepa recurso. 


\section{a) Competencia objetiva}

En primer lugar destaca que conocerá en única instancia "de los recursos que se deduzcan en relación con las disposiciones generales y los actos de los Ministros y de los Secretarios de Estado en general y en materia de personal cuando se refieran al nacimiento o extinción de la relación de servicio de funcionarios de carrera. Asimismo conocerá de los recursos contra los actos de cualesquiera órganos centrales del Ministerio de Defensa referidos a ascensos, orden y antigüedad en el escalafonamiento y destinos" (art. 11.1.a LJCA).

Se hace de ese modo una distinción entre el Ministerio de Defensa y el resto que no se entiende ${ }^{48}$. Entre otras cosas, cuando se trate del Ministerio de Defensa, no solamente conocerá cuando se trate del nacimiento o extinción de la relación de servicio, sino también respecto de actos de cualesquiera órganos centrales del mismo referidos a ascensos, orden y antigüedad en el escalafonamiento y destinos que en principio habría de conocerse si no existiera esta previsión legal expresa por los juzgados centrales de lo contencioso-administrativo ${ }^{49}$.

Igualmente, conocerán de los asuntos previstos en el art. 11. b), c) y d) $\operatorname{LJCA}^{50}$ :

\section{b) Competencia funcional}

Que les corresponde desde la creación de los juzgados centrales de lo contencioso-administrativo. Conocerá, en segunda instancia, de las apelaciones contra autos y sentencias dictados por estos y de los correspondientes recursos de queja (art. 11.2 LJCA).

Además de las cuestiones de competencia entre los juzgados centrales de lo contencioso-administrativo, conocerá de los mal llamados recursos de revisión contra sentencias firmes dictadas por estos (art. 11.3 y 4 LJCA).

RuIz: (n. 32), p. 180.

49 Como indican Del Cacho Frago, A., y Vacas García Alós, L, Comentarios a la ley de la jurisdicción Contencioso-Administrativa, La Ley, Madrid, 1998, p. 62, cualquier otra materia quedaría claramente residencia en los juzgados centrales de lo contencioso-administrativo.

50 Dispone que "b) De los recursos contra los actos de los Ministros y Secretarios de Estado cuando rectifiquen en vía de recurso o en procedimiento de fiscalización o de tutela los dictados por órganos $o$ entes distintos con competencia en todo el territorio nacional. c) De los recursos en relación con los convenios entre Administraciones públicas no atribuidos a los Tribunales Superiores de Justicia. d) De los actos de naturaleza económico-administrativa dictados por el Ministro de Economía y Hacienda y por el Tribunal Económico-Administrativo Central, con excepción de lo dispuesto en el artículo $10.1 \mathrm{e})$ ". 


\section{E) Sala de lo Contencioso-Administrativo del Tribunal Supremo}

El Tribunal Supremo es el órgano que agota cúspide jurisdiccional y su ámbito territorial se extiende a toda España. Tiene competencia tanto objetiva como funcional.

\section{a) Competencia objetiva}

Su Sala de lo Contencioso-Administrativo (Sala $3^{\text {a }}$ ) conocerá en única instancia de los recursos que se deduzcan en relación con los actos y disposiciones del Consejo de Ministros y de las Comisiones Delegadas del Gobierno, y del Consejo General del Poder Judicial. Así como de los actos y disposiciones en materia de personal, administración y gestión patrimonial adoptados por los órganos competentes del Congreso de los Diputados, del Senado, del Tribunal Constitucional, del Tribunal de Cuentas y del Defensor del Pueblo (art. 12.1 LJCA).

\section{b) Competencia funcional}

Y por lo que se refiere a la competencia funcional, conocerá de "los recursos de casación de cualquier modalidad, en los términos establecidos por esta Ley, y los correspondientes recursos de queja" (art. 12.2.a LJCA). Así como también del recurso de casación y de la revisión contra las resoluciones dictadas por el Tribunal de Cuentas, con arreglo a lo establecido en su Ley de Funcionamiento. Y también de los "recursos" de revisión contra sentencias firmes dictadas por las Salas de lo Contencioso-Administrativo de los Tribunales Superiores de Justicia, de la Audiencia Nacional y del Tribunal Supremo, salvo lo dispuesto en el art. $61.1 .1^{\circ}$ LOPJ $^{51}$.

\section{Competencia territorial}

La competencia territorial se determina con aparente sencillez en el art. 14 LJCA. La regla general será la competencia del órgano jurisdiccional en cuya circunscripción tenga su sede el órgano que hubiere dictado la disposición o el acto originario impugnado.

51 Según este precepto: "Una Sala formada por el Presidente del Tribunal Supremo, los Presidentes de Sala y el Magistrado más antiguo y el más moderno de cada una de ellas conocerá: $1^{\circ}$ De los recursos de revisión contra las sentencias dictadas en única instancia por la Sala de lo ContenciosoAdministrativo de dicho Tribunal". 
Sin embargo, la cuestión no está exenta de problemas e incertidumbres $^{52}$. Estas se salvan en cierto modo en materia de personal, puesto que el punto segundo del mismo precepto determina que será competente, a elección del demandante, junto al anterior, el juzgado o tribunal en cuya circunscripción tenga aquel (el demandante) su domicilio. Regla que, no obstante, no operará cuando el acto originario impugnado afectase a una pluralidad de destinatarios y fueran diversos los Juzgados y Tribunales según las reglas anteriores.

Significa esto último que, si son varios los demandantes y tienen el domicilio todos ellos en la misma demarcación del órgano jurisdiccional, podrán formular su demanda también en el de su domicilio. Solamente cuando pudieran ser territorialmente competentes varios órganos, se entenderá competente único el que fija la regla general del art. 14.1 $\mathrm{LJCA}^{53}$.

Con todo, esta regla de atribución competencial puede plantear importantes problemas "logísticos", en tanto en cuanto cabe la posibilidad de que enjuicien órganos jurisdiccionales sobre órganos administrativos fuera de su circunscripción judicial, llegando incluso al caso de que los Tribunales Superiores de Justicia no tendrán el monopolio en la aplicación e interpretación del correspondientes derecho administrativo autonómico, exenta de la posibilidad de ser unificada ${ }^{54}$.

\section{ESPECIALIDADES PROCESALES EN MATERIA DE PERSONAL CON IN- DEPENDENCIA DEL PROCEDIMIENTO ADECUADO}

Como se ha indicado antes, algunas especialidades han sido previstas con independencia del procedimiento en que se ventile la pretensión basada en una cuestión de personal. Junto con algunas particularidades respecto de la cuantía y la prueba, destaca la previsión del art. 110

52 Véase Garberí llobregat, J., "La competencia judicial en la nueva Ley", en Vv. Aa., La nueva Ley de la Jurisdicción Contencioso-Administrativa. Estudio y aplicación práctica de la Ley 29/1998, (Dir.: GARBERí; coor.: MARTín), Colex, Madrid, 1999, pp. 46 y ss.

53 Dispone el mismo que "1. La competencia territorial de los Juzgados y de los Tribunales Superiores de Justicia se determinará conforme a las siguientes reglas: Primera. Con carácter general, será competente el órgano jurisdiccional en cuya circunscripción tenga su sede el órgano que bubiere dictado la disposición o el acto originario impugnado. Segunda. Cuando el recurso tenga por objeto actos de las Administraciones públicas en materia de personal, propiedades especiales y sanciones será competente, a elección del demandante, el Juzgado o el Tribunal en cuya circunscripción tenga aquel su domicilio o se balle la sede del órgano autor del acto originario impugnado. (...) 2. Cuando el acto originario impugnado afectase a una pluralidad de destinatarios y fueran diversos los Juzgados o Tribunales competentes según las reglas anteriores, la competencia vendrá atribuida al órgano jurisdiccional en cuya circunscripción tenga su sede el órgano que bubiere dictado el acto originario impugnado".

54 Garberí: (n. 52), pp. 49-51. 
LJCA que permite extender subjetivamente la eficacia de cosa juzgada de la sentencia a otras personas en ciertos casos.

\section{Determinación de la cuantía (art. 42.2 LJCA)}

Ya hemos visto antes cómo se determinará la cuantía, siendo que esta se reputará indeterminada por el mero hecho de que la pretensión se refiera a los funcionarios públicos y no verse sobre derechos o sanciones susceptibles de valoración económica (art. 42.2 LJCA).

Esta previsión parece tener en principio cierta trascendencia, puesto que los actos procesales que dependan de la condición de superar determinadas cuantías quedarán vedadas para estos. Siendo sobre todo relevante esta cuestión a los efectos de la formulación de los correspondientes recursos de apelación (art. 81.1.a LJCA); y casación en sus diversas modalidades (arts. 86.2,b) y 96.3 y 99.2 LJCA). Y de otro lado, a efectos de una eventual condena en costas, se entenderá que su cuantía es de 18.000 a efectos del límite cuantitativo de un tercio previsto en el art. 394.3 LEC. Y que viene a coincidir al final con el límite máximo de 6.000 euros para la sanción por mala fe procesal (art. 247.3 LEC).

Concretamente en relación con el recurso de apelación, el tenor literal del art. 81.1 LJCA parece indicar que, por ser la cuantía indeterminada, las materias de personal quedarán vedadas del citado recurso. Así, autores como GARRIDO FALlA 55 , afirman que "como regla general, pues, las cuestiones de personal son resueltas en única instancia por órganos judiciales unipersonales en el marco del procedimiento abreviado". Y así parece que lo ha entendido en ciertos casos por la jurisprudencia. Así, por ejemplo, en relación con un asunto en materia de personal, el TC entiende que, no habiendo formulado apelación, porque expresamente se indicó la improcedencia de la misma en la sentencia del juzgado de lo contencioso-administrativo ${ }^{56}$.

Sin embargo, la jurisprudencia mayoritaria parte de postulados bien distintos, considerando que precisamente el carácter de indeter-

ss GARRIDO: (n. 27), p. 266,

56 Dice la STC 79/2004, 5 mayo, que "partiendo de la idea básica expuesta de que la determinación de la procedencia o improcedencia de los recursos es una cuestión de legalidad ordinaria que compete interpretar de modo exclusivo a los Juzgados y Tribunales, lo cierto es que el órgano judicial al que competía la interpretación respecto de la pertinencia o no de un posterior recurso de apelación entendió que el mismo era improcedente, y así lo dijo de modo expreso en la advertencia de recursos contenida en la Sentencia que abora se recurre. Ello, unido a que el tenor del art. 81 LJCA exige una cierta interpretación en conjunción con otros preceptos de la misma norma que no nos corresponde efectuar, nos conduce, de acuerdo con el principio pro actione que debe presidir el recurso de amparo en supuestos en los que la interpretación del precepto legal no es patente, tal y como ocurre con el abora enjuiciado, a la inadmisión del óbice procesal alegados". 
minado de las cuestiones de personal autorizan el acceso a la apelación $^{57}$.

\section{Prueba (art. 60.3 LJCA)}

Una previsión que, aunque pueda ser de un modo más o menos remoto o tangencial, puede afectar a cuestiones de personal es la del art. 60.3 LJCA en materia de prueba. Dispone que en el caso de que se trate de sanción disciplinaria, en tanto en cuanto pueda suponer o no la extinción de la relación de servicio del funcionario de carrera, se recibirá siempre el proceso a prueba cuando exista disconformidad en los hechos.

Sobre el particular, afirma GonZÁlez-Cuellar que tal previsión, aunque pueda parecer que dispensa mayores garantías al demandante, no tiene mucho sentido y constituye una espada de doble filo para los derechos del sancionado: si recae sobre hechos intrascendentes, la apertura resulta intrascendente e inútil; no parece lógico colocar en situación de igualdad a demandante y demandado ante una disconformidad sobre los hechos en materia sancionadora pues rige la presunción de inocencia y a la Administración incumbe la carga de la prueba, si no consta la prueba documentada y la administración ni siquiera solicita el recibimiento del pleito a prueba, "el órgano jurisdiccional no tendría que asumir su papel, en demérito de su neutralidad"58.

57 Así se pronuncian, por ejemplo, las SSTSJ Castilla-La Mancha (Sala de lo ContenciosoAdministrativo, Secc. $1^{2}$ ), 9 octubre 2002, RJCA 2002/1161; Aragón (Sala de lo Contencioso-Administrativo, Secc. $1^{2}$ ), 25 octubre 2002, JUR 2003/133012; Granada (Sala de lo Contencioso-Administrativo, Secc. $1^{\text {a }}$ ), 2 diciembre 2002, RJCA 2003/64164; o Madrid (Sala de lo Contencioso-Administrativo, Secc. 6*), 6 junio 2001, RJCA 2002/350. Según esta última, "el art. 81 de la LJCA dispone que las sentencias de los Juzgados de lo Contencioso-Administrativo (entre otras) serán susceptibles de recurso de apelación, excepto que se bubieran dictado en los asuntos siguientes: a) aquellos cuya cuantia no exceda de tres millones de pesetas, b) los relativos a materia electoral comprendidos en el art. 8.4. En este supuesto se alega que el recurso sería inadmisible debido a la cuantía del mismo. Sin embargo, no puede considerarse que se trate de un asunto de cuantía inferior a tres millones de pesetas, puesto que se ba sancionado al recurrente con una sanción de pérdida de dos años y once meses de funciones y remuneración y otra falta, con sanción de pérdida de dos años y un mes de funciones y remuneración. Con independencia del montante económico de las remuneraciones dejadas de percibir, en estas sanciones de pérdida de función existe un componente de carácter no cuantificable, moral o de contenido más amplio, que en definitiva, obliga a considerar que el asunto es de cuantía indeterminada. Por lo demás, la redacción del texto del art. 81 es claramente "pro" recurso, puesto que considera que todas las sentencias son apelables, "excepto" los supuestos que menciona, lo que significa en definitiva que el criterio ba de ser amplio, y no impedir la apelación excepto en supuestos en que evidentemente no proceda aquella".

58 González-Cuellar Serrano, N., "Sección 6. Prueba", en Vv. AA., Comentarios a la nueva Ley Reguladora de la Jurisdicción Contencioso-Administrativa de 1998 (con otros). Centro de Estudios Ramón Areces, S. A., Madrid, 1999, pp. 475-6. 
En cualquier caso, aunque habla de "se recibirá siempre", la jurisprudencia ha puesto de manifiesto que se trata de una facultad del órgano jurisdiccional, no un derecho de las partes ${ }^{59}$. Ahora bien, con todo, no ha de confundir recibimiento del pleito a prueba con admisión de todos y cada uno de los medios de prueba ${ }^{60}$.

Y en relación con el art. 74 LJCA 1956, básicamente coincidente con el vigente art. 60.3 LJCA, pone de manifiesto la STS, Sala $3^{a}$, Secc. $6^{a}$, 6 febrero 2003, RJ 2003/1043 que no resulta contradictorio entender que la carga de la prueba recae sobre el recurrente y al mismo tiempo declarar no haber lugar a la misma por cuanto el mismo art. 74 exige para la admisión del recibimiento a prueba que se efectúe por otrosí en la demanda con expresión de los hechos sobre los que ha de versar.

\section{Extensión de los efectos del fallo a quienes no han sido parte (art. 110 LJCA)}

En principio, la regla que establece el art. 110 LJCA es que las sentencias de inadmisibiliad y desestimatorias producen efectos exclusivamente entre las partes, mientras que las estimatorias, dándose determinadas circunstancias, pueden extenderse a quienes no lo han sido ${ }^{61}$. De ahí que cabe afirmar que la sentencia a extender ha de ser declarativa y de las previstas en el art. $71 .^{\circ}$.b) LJCA, esto es, de "reconocimiento y restablecimiento de una situación jurídica individualizada" 62 .

59 GonZÁlez-Cuellar: (n. 58), pp. 476, cita la "STS 15.1.91".

60 A tal efecto, como indica la STS, Sala 3", Secc, 6a, 12 abril 2004, RJ 2004/2613, " $l o$ que cuestiona el recurrente no es algo que le fuera negado. Los preceptos que invoca se refieren al recibimiento a prueba y a los supuestos en los que no se puede denegar ese trámite de admisión. La Sala no los infringió sino que admitió el proceso a prueba, sin perjuicio de que más tarde, y en el trámite de aceptación de los medios propuestos, sobre cuya admisión la Sala ba de decidir del modo que considere conforme a Derecho, rechazase uno de ellos".

61 El art. 72 LJCA es ilustrativo de esta regla general cuando dispone que: "1. La sentencia que declare la inadmisibilidad o desestimación del recurso contencioso-administrativo solo producirá efectos entre las partes. 2. La anulación de una disposición o acto producirá efectos para todas las personas afectadas. Las sentencias firmes que anulen una disposición general tendrán efectos generales desde el día en que sea publicado su fallo y preceptos anulados en el mismo periódico oficial en que lo bubiera sido la disposición anulada. También se publicarán las sentencias firmes que anulen un acto administrativo que afecte a una pluralidad indeterminada de personas. 3. La estimación de pretensiones de reconocimiento o restablecimiento de una situación jurídica individualizada solo producirá efectos entre las partes. No obstante, tales efectos podrán extenderse a terceros en los términos previstos en los artículos 110 y 111".

62 Además, en opinión de Gimeno Sendra, V., Derecho Procesal Administrativo (con otros), Colex, $2^{a}$ ed., Madrid, 2004, pp. 282-3, ha de ser firme, sin que quepa recurso ordinario, extraordinario ni siquiera revisión e interés de ley, aunque no afecten a la cosa juzgada. Sobre esta cuestión dice el ATS, Sala 3", Secc. 2a, 21 diciembre 2001, RJ 2002/518, "que se trate de una sentencia estimatoria, requisito no mencionado expresamente por el artículo 110 de 
Ahora bien, dadas las especiales características del derecho administrativo, en el que determinados actos, resoluciones y disposiciones pueden afectar a una pluralidad de partes, a los efectos de extender la extensión de los efectos a los sujetos titulares de la relación jurídica material reconocida en otra sentencia firme, provocada por otros litisconsortes diligentes, poder eludir la interposición de un nuevo recurso contencioso-administrativo (no de la vía administrativa previa) y acudir directamente al proceso de ejecución a fin de reconocer también el reconocimiento judicial ${ }^{63}$. Así, cabrá la extensión de efectos a personas distintas de las partes siempre que se trate, entre otra, de cuestiones de personal, con independencia del tipo de cuestión de que se trate o del procedimiento adecuado (no en vano el art. 110.4 LJCA se refiere al "juez o tribunal", cuando se den las circunstancias del citado art. 110 LJCA $^{64}$.

Modificado por la Disposición Adicional 14.8 de la LO 19/2003, 23 diciembre, el art. 110 LJCA previene la extensión de los efectos de la sentencia firme en materia de personal en los términos que prevé. El fundamento de esta extensión, en opinión de Gimeno, hay que encontrarlo en la STC 10/1998 y reiterada por las SSTC 23 a 28/1998, y en última instancia, en el principio constitucional de igualdad en la aplicación de la ley, puesto que sería contrario al referido principio y al derecho a la tutela judicial efectiva y a un proceso sin dilaciones indebidas que los litisconsortes inactivos que no formularon recurso contencioso-administrativo se vieran discriminados ante quienes interpusieron recurso en tiempo y forma. Se trata de extender los límites subjetivos de la cosa juzgada material a quien no fueron partes formales en el proceso declarativo, aunque deben beneficiarse por igual de los efectos materiales de la cosa juzgada por ser litisconsortes ${ }^{65}$. Así y todo, no se trata de una extensión automática sino que es necesario aplicar las previsiones del art. $110 \mathrm{LJCA}$ en una labor interpretativa puesto

la Ley 29/1998, de 13 de julio, pero que es inherente sustancialmente a la extensión de los efectos en vía de ejecución, pues carecería de sentido predicar este requisito en sentencias que se limitan a declarar la inadmisibilidad del recurso o la desestimación del mismo, pues, en ambos casos, no puede haber reconocimiento de una situación jurídica individualizada. Este requisito ba sido confirmado indirectamente por el artículo 72, apartado 1, de esta misma Ley, en cuanto dispone que: '1. La sentencia que declare la inadmisibilidad o desestimación del recurso contencioso-administrativo solo producirá efectos entre las partes'".

63 Gimeno: (n. 62), p. 281.

64 La Exposición de motivos LJCA, VI, 3, párrafo cuarto alude a esta cuestión cuando señala que: "Dos novedades importantes completan este Capítulo de la Ley. La primera se refiere a la posibilidad de extender los efectos de una sentencia firme en materia de personal y en materia tributaria a personas distintas de las partes que se encuentren en situación idéntica. Aun regulada con la necesaria cautela, la apertura puede aborrar la reiteración de múltiples procesos innecesarios contra los llamados actos en masa...".

65 Cfr. Gimeno: (n. 62), pp. 281-2. 
que la economía procesal y la celeridad no pueden ser contrarias a la seguridad jurídica ${ }^{66}$.

Así, por tanto, para la extensión de los efectos es preciso que se den los requisitos que enumera el citado art. $110 \mathrm{LJCA}^{67}$, siempre con una interpretación adecuada conforme al art. 3.1 CC, y en especial a que cumpla con la finalidad de evitar recursos masivos e innecesarios y propiciar la economía procesal ${ }^{68}$. Estos requisitos, por lo que ahora nos interesa, consisten en:

1. ${ }^{\circ}$ Que se trate, además de tributaria, de materia de personal al servicio de la Administración Pública ${ }^{69}$. Aunque cabría incluir otras, estas son susceptibles, sin duda, de afectar a un gran número de situaciones idénticas $\mathrm{y}$, además, en las que no ha de darse agravio comparativo alguno ${ }^{70}$.

2. ${ }^{\circ}$ Que se dé una situación de identidad. A tal efecto, habrá de atenderse a lo que es objeto del proceso, esto es, siempre que se den las identidades subjetivas y objetivas necesarias, esto es, que se trate de la misma Administración Pública y que se trate del mismo petitum y causa petendi de la pretensión ${ }^{71}$. De lo contrario, se produciría en el fondo una falta de congruencia con el objeto del propio proceso ${ }^{72}$. Los interesados

66 Álvarez-Cienfuegos SuÁrez, J. M., y González Rivas, J. J., Análisis teórico y jurisprudencial de la Ley de la Jurisdicción Contencioso-Administrativa. Ley 29/1998, de 13 de julio, Aranzadi, Pamplona, 1998, p. 315.

67 Sobre todos los aspectos del art. 110 LJCA, véase Martín Contreras, L., La extensión de efectos de las sentencias en la jurisdicción contencioso-administrativa en materia tributaria y de personal, Comares, Granada, 2000.

68 De especial interés sobre esto son las palabras de la STSJ Cataluña, Sala Contencioso-Administrativo, Secc. $1^{\text {a }}$, 26 septiembre 2001, RJCA 2001/1320, cuando dice que: "De cuanto ba quedado transcrito se desprende la necesidad de una interpretación del art. 110 LJCA que, de acuerdo con el art. 3.1 del Código Civil, además del sentido propio de sus palabras, atienda al contexto y a los antecedentes legislativos, $y$, fundamentalmente, al espiritu y finalidad de la norma. La finalidad, tanto del art. 110 como de los citados arts. 37.2 y 51.2 LJCA, no es otra que hacer frente a la situación de este orden jurisdiccional, destacando su Exposición de Motivos que 'ba sufrido hasta la saturación el extraordinario incremento de la litigiosidad', así como que el mismo 'está atravesando un periodo crítico ante el que es preciso reaccionar mediante las oportunas reformas'. De entre tales reformas destacan por su novedad las relativas a la presencia de fenómenos masivos de recursos, suscitados por pluralidad de recurrentes respecto de resoluciones administrativas de contenido idéntico e impugnadas por motivos del todo análogos, pero siempre con el designio de propiciar el principio de economía procesal y de evitar la reiteración de múltiples procesos innecesarios".

69 En opinión de MarTín: (n. 67), p. 16, deberá hacerse la interpretación más extensiva y amplia posible, de forma que será aplicable a todos los supuestos de impugnación de actos o disposiciones referidas en general a la condición funcionarial, aunque quien lo impugne no reúna la condición de funcionario, por ejemplo, por impugnar una convocatoria de proceso de selección por quien todavía no ha alcanzado la condición de funcionario.

70 Ruiz: (n. 32), p. 296.

71 Sobre los elementos que configuran el objeto del proceso, véase, entre otros, Ortells: (n. 25), pp. 239-58.

72 Álvarez-Cienfuegos: (n. 66), p. 315. 
han de encontrarse en idéntica situación jurídica que los favorecidos, se exige una igualdad sustancial, no siendo suficiente una similitud más o menos acentuada ${ }^{73}$. Para CoRDón ${ }^{74}$, resulta un concepto preciso y fácilmente apreciable en la generalidad de los casos, de modo que le llama la atención que no pueda controlarse a limine 75 .

Sobre la identidad, se ha elaborado una reiterada doctrina jurisprudencial en relación con la extensión de los efectos de sentencia en la que el actor solicitó vacaciones y fue considerada contraria a derecho la negativa de la administración, sin que pueda extenderse a quienes solicita la extensión en reclamación de indemnización cuando no la solicitó en vía administrativa. Como dice la STS, Sala $3^{\mathrm{a}}$, Secc. $7^{\mathrm{a}}, 13$ julio 2004, RJ 2004/6969, en este caso, "es claro que las situaciones son diferentes" 76 .

$3 .^{\circ}$ Que el órgano jurisdiccional sentenciador fuera competente territorialmente para conocer de las pretensiones a extender. Ha de tenerse en cuenta que en materia de personal, el art. 14.1.2 $2^{\mathrm{a}}$ LJCA dispone que "cuando el recurso tenga por objeto actos de las Administraciones públicas en materia de personal, propiedades especiales y sanciones será competente, a elección

73 Moscoso Torres, P. J., "El recurso contencioso-administrativo (II): Innovaciones procedimentales (acumulación, prueba y sentencia)", en Vv. AA., La nueva Ley de la Jurisdicción Contencioso-Administrativa. Estudio y aplicación práctica de la Ley 29/1998, (Dir.: GARBERÍ; coor: Martín), Colex, Madrid, 1999, p. 252.

74 CORdón: (n. 39), p. 267.

75 Dice la STS, Sala $3^{\mathrm{a}}$, Secc. $7^{\mathrm{a}}, 13$ julio 2004, RJ 2004/6969 que "el artículo 110.1 a) es terminante a este respecto: exige que sean, no semejantes, ni parecidas, similares o análogas, sino idénticas. Por tanto, es preciso operar con extremo cuidado a la bora de comprobar si existe o no esa identidad. Naturalmente tal requisito debe entenderse en sentido sustancial. Es decir, la Ley de la Jurisdicción está pidiendo que sean las mismas las circunstancias de becho y las pretensiones jurídicas que sobre ellas se fundamentan en un caso y en el otro". No obstante, conviene tener en cuenta las palabras de la citada STSJ Cataluña, Sala Contencioso-Administrativo, Secc. $1^{a}$, 26 septiembre 2001, RJCA 2001\1320, sobre este aspecto cuando dice que "las técnicas utilizadas no siempre son acordes con los conceptos técnico jurídicos tradicionales relativos al objeto procesal, la relación juridica discutida o la igualdad de procesos. Asi, la 'identidad' de objeto que se predica en el art. 37.2 no coincidirá siempre con la tradicional doctrina de las identidades procesales, al tiempo que babrá de interpretarse con amplitud la 'sustancial' identidad del art. 51.2. Lo mismo ocurre con el requisito de la 'idéntica situación jurídica' del art. 110.1.a), que no cabe identificar, ni siquiera atendiendo al sentido propio de las palabras, con el concepto tradicional de relación jurídica, que por sus propias características, impediría la efectiva aplicación de la norma, conclusión esta que debe excluirse de raiz, pues las normas jurídicas ban de recibir en todo caso una interpretación que las haga aplicables conforme a la intención del legislador y no otra inteligencia que, en la práctica, las convierta en meras declaraciones de intenciones".

76 De modo que, como dice la STS, Sala 3a, Secc. $7^{\mathrm{a}}$, 21 septiembre 2004. RJ 2004/6519 (y en el mismo sentido otras muchas, como la STS 13 septiembre 2004, RJ 2004/5610) "el art. 110,1, a) de la Ley de esta Jurisdicción, que no se refiere a semejanza, similitud o analogia, sino a 'identidad', que ba de entenderse que solo concurre cuando sean las mismas las circunstancias de becho y las pretensiones juridicas que sobre ellas se fundamentan, en un caso y en el otro, pudiendo destacarse, además, que no consta que el abora solicitante de la extensión de efectos verificara petición alguna en cuanto a las aludidas vacaciones de 1994, y sí solo que no las disfrutó, por lo que no 
del demandante, el Juzgado o el Tribunal en cuya circunscripción tenga aquel su domicilio o se halle la sede del órgano autor del acto originario impugnado".

En materia de personal el tenor literal de este precepto plantea un grave problema, dado que la competencia territorial es electiva, a elección del demandante, el juzgado o tribunal en cuya circunscripción tenga su domicilio o se halle la sede del órgano autor del acto originario impugnado (art. 14.1.2 $2^{\mathrm{a}}$ LJCA). Parece claro que a pesar del tenor de este precepto, el competente para conocer de la extensión será única y exclusivamente el órgano ejecutor de la sentencia firme, puesto que siendo incidental de una ejecución, el órgano competente ha se ser el ejecutor puesto que lo es para todas las incidencias de la misma según el art. 4 LJCA, siendo que dicha competencia la ostenta únicamente quien haya conocido del asunto en primera o única instancia en virtud del art. $103.1^{\circ} \mathrm{LJCA}^{77}$.

concurre la identidad exigida, lo que impone que ba lugar al recurso de casación interpuesto por el Abogado del Estado y que ban de anularse los Autos recurridos, resolviendo que no procede la extensión de efectos pretendida abora".

77 GIMENO: (n. 62), p. 284. Por su parte, dice la STSJ Granada, Andalucía, Sala de lo Contencioso-Administrativo, Secc. $2^{\mathrm{a}}, 18$ marzo 2002. RJCA $2002 \backslash 584$ que "de todo to regulado en el referido art. 110 LJCA se concreta que el órgano judicial competente para conocer de la petición de extensión de efectos de una concreta sentencia es el que la bubiere dictado, porque este precepto alude a este órgano como el 'Juez o Tribunal de ejecución', siendo uno de los requisitos para que proceda tal solicitud que el Juez o Tribunal sentenciador fuera también competente, por razón del territorio, para conocer de las pretensiones de reconocimiento de una situación individualizada -a la que se pretenden extender los efectos de la sentencia ya dictada y firme-. Además, al configurarse esta solicitud - de extensión de los efectos de una sentencia-como un trámite incidental, regulado en el Capítulo IV del Título IV de la LJCA de 13 de julio de 1998, bajo la rúbrica de 'Ejecución de sentencias', debe serle de aplicación el art. 103.1 de la Ley ritual que precisa que el ejercicio de la potestad de hacer ejecutar las sentencias y demás resoluciones judiciales corresponde al Juzgado o Tribunal que baya conocido del asunto en primera o única instancia. Todo ello, señala al Juzgado que dicto la sentencia firme cuyos efectos pretenden extenderse a otro supuesto presumiblemente idéntico (el de lo contencioso-administrativo núm. I de Granada) como el competente para conocer de la petición formulada a la luz del art. 110 LJCA. La normativa anteriormente referida, tan específica en la materia y en el orden jurisdiccional contencioso-administrativo, supone desplazar la aplicación de una norma tan genérica como es la aludida por el juzgador de instancia en su auto, objeto del presente recurso de apelación: el art. 167 LOPJ; estimándose que su aplicación al presente supuesto no es ajustado ni certero; suponiendo sobre todo una vulneración al derecho fundamental de defensa, regulado constitucionalmente en el art. 24, porque con su apreciación se ba procedido a rechazar el fondo de la petición formulada por el ciudadano sin entrar a analizar su procedencia o no, sino por simples causas o circunstancias formales, como las relativas al reparto de los asuntos entre los diversos órganos territorial y materialmente competentes, requisitos procedimentales que, por añadidura, no son de aplicación en los trámites incidentales del art. 110 LJCA. Por ello, estimándose nula la resolución judicial impugnada, deben devolverse las actuaciones al Juzgado de procedencia a los efectos de tramitar el incidente regulado en el tan referido art. 110 LJCA, resolviéndolo mediante auto, cuyo contenido estimatorio o desestimatorio de la petición formulada dependerá, eminentemente, de la concurrencia o no de identidad entre la situación jurídica individualizada reconocida en la sentencia de 1-9-2000, y la situación planteada en el incidente". 


\section{4. ${ }^{\circ}$ Procedimiento:}

\section{A) Solicitud:}

- Instancia de quien pretenda beneficiarse de la extensión de los efectos mediante solicitud por escrito razonado y con aporte probatorio documental que acredite la identidad de situaciones o la no concurrencia de las situaciones a que se refieren el art. 110.5 LJCA. Aunque la disyuntiva ha sido criticada $^{78}$, en mi opinión se presenta correcta en cuanto no parece oportuno exigir la prueba de circunstancias que, al menos eventualmente, será imposible probar por tratarse de hechos negativos (la llamada "prueba diabólica"). En definitiva, el precepto no impone la prueba de que no existe cosa juzgada, no es contraria a la jurisprudencia o no se ha dictado resolución que, habiendo causado estado en vía administrativa, fuere consentida y firme por no haber promovido recurso contenciosoadministrativo, sin perjuicio de que eventualmente alguno de tales elementos, sobre todo en contradicción con su afirmación, pueda ser objeto de prueba.

- El escrito se dirigirá directamente al órgano jurisdiccional que dictó la resolución a extender, habiendo eliminado la LO 19/2003 el trámite previo de dirigirse a la Administración que dictó el acto o que deba proceder a extender sus efectos.

- Se solicitará en el plazo de un año desde la última notificación de la sentencia a quienes fueron parte en el proceso, o de la sentencia en caso de recurso en interés de ley o de revisión ${ }^{79}$.

B) Informe y alegaciones:

- Dentro de los 20 días siguientes a la solicitud, el Juez o tribunal recabará de la Administración los antecedentes que estime oportunos $y$, en todo caso, un informe detallado sobre la viabilidad de la extensión solicitada

- Se pondrá de manifiesto el resultado de esas actuaciones a las partes para que aleguen por plazo común de tres días, con emplazamiento,

78 Para Ruiz: (n. 32), p. 297, la disyuntiva es incorrecta porque -en su opinión- habrá de acreditarse tanto la identidad como que no existe alguna de las circunstancias que a pesar de dicha identidad imposibilite la extensión de los efectos.

79 Afirma Gimeno: (n. 62), p. 284 que, no se descontarán los días inhábiles por tratarse de un plazo de caducidad (art. 46 LJCA). Si se hubiere formulado revisión o recurso en interés de ley, el dies a quo del plazo computará desde la notificación que ponga fin a este, pero como sea que quien solicite la extensión no tiene por qué conocer los mismos, habrá de presentarlos en un año, sin perjuicio de que queden en suspenso hasta su resolución. 
en su caso, de los interesados directamente afectados por los efectos de la extensión.

\section{C) Resolución:}

- Una vez evacuado el trámite, resolverá sin más por medio de auto, en el que no podrá reconocerse una situación jurídica distinta a la definida en la sentencia firme de que se trate. Frente a esta resolución cabrá apelación ${ }^{80}$.

- La desestimación (o, quizá, más bien, en algunos casos la inadmisión ${ }^{81}$ ) se producirá, únicamente, cuando falten los requisitos señalados así como cuando, existiera cosa juzgada (en su caso, habría de acudirse a un proceso de ejecución autónomo), la doctrina determinante del fallo cuya extensión se postule fuere contraria a la jurisprudencia del Tribunal Supremo o a la doctrina sentada por los Tribunales Superiores de Justicia en el recurso a que se refiere el artículo 99, o si para el interesado se hubiere dictado resolución que, habiendo causado estado en vía administrativa, fuere consentida y firme por no haber promovido recurso Contencioso-Administrativo ${ }^{82}$.

80 En principio, parece que si la sentencia a extender fuera inapelable, también lo será el auto en cuestión, y viceversa, siendo admisible en ambos efectos, sin perjuicio de la posibilidad de ejecución provisional. Ahora bien, como apunta Alonso MÁs, Mª. J., "Reflexiones sobre la nueva regulación de la extensión de los efectos de las sentencias", en Revista de Administración Pública, mayo-agosto 2004, p. 300, hay casos en que ha de ser apelable si, por ejemplo, la cuantía a que se refiere el auto de extensión de efectos es superior a la apelación. No obstante, en mi opinión, si la naturaleza de este procedimiento es incidental, por efecto de la litispendencia, las variaciones en relación con la cuantía, habría de impedir tal consideración. Otra cosa es que por la distinta naturaleza de la resolución a apelar y de la propia naturaleza de la extensión pudieran permitir una interpretación favorable a su recurribilidad. Como dice, aunque sea a otros efectos, Robles Garzón, J. A., "Los recursos en la nueva Ley de la Jurisdicción Contencioso-Administrativa", en Revista del Poder Judicial, núm. 58,2000, pp. 347-8, nos encontramos ante un supuesto de proceso incidental autónomo y, por supuesto, ha de ser analizado en sí mismo y por sí. Y en el mismo sentido, CoRdón: (n. 39), p. 267, afirma que "más que ante un incidente en la ejecución nos encontramos ante un proceso incidental -especial (...)- inserto en la fase de ejecución de una sentencia, cuya razón de ser es la simplicidad de su tramitación y la apreciación no problemática de la concurrencia de sus presupuestos".

81 CORdón: (n. 39), p. 268.

82 Sobre este último requisito, véase STS, Sala 3a, Secc, 7ª, 26 abril 2004, RJ 204/2782. Igualmente, la STS, Sala $3^{\text {a }}$, Secc. $7^{\mathrm{a}}$, 24 mayo 2004. RJ 2004/4059, indica que puede ser observado incluso de oficio. Y la STS, Sala $3^{\mathrm{a}}$, Secc, $7^{\mathrm{a}}$, 22 junio 2004. RJ 2004/3861 explica que el hecho de no promover los recursos ante la administración supone que las resoluciones en vía administrativa quedaron firmes y consentidas. Asimismo, sobre el mismo, en opinión de Alonso: (n. 80), pp. 296-7, 303 y ss., aparte de problemas terminológicos y prácticos, puede plantear incluso problemas de constitucionalidad, pues la aplicación de la teoría del acto consentido impide a los órganos jurisdiccionales reparar la desigualdad de tratamiento que se causa en los casos en que unos afectados hayan recurrido el acto con éxito y otro no. 
En el caso de que no sea viable, queda la duda de si no tiene ningún efecto o de si sería trasladable las previsiones sobre inejecución y de sentencias por imposibilidad legal o material ${ }^{83}$.

Por último, solamente indicar que no debe confundirse el supuesto previsto en el art. 110 con el del 111, puesto que en este último caso se trata de que, por economía procesal, quedan en suspenso los procesos ya iniciados con el fin de no acumularlos al que constituye proceso "tipo" o "testigo". Una vez resuelta esta, se notificará a las partes de los procesos suspendidos, quienes podrán optar por solicitar la extensión en los términos del art. 111, por continuar su propio procedimiento o por el desistimiento.

\section{ESPECIALIDAdes PROCESAles PARA LAS MATERIAS DE PERSONAL EN DETERMINADOS SUPUESTOS}

Otras especialidades se han previsto únicamente aplicables cuando dentro de las materias de personal, la cuestión no implique "separación de empleados públicos inamovibles" (arts. 23.3 y 85.3 LJCA), o no se refieran al "nacimiento o a la extinción de la relación de servicio de funcionarios de carrera" (art. 86.2.a) LJCA).

Estas especialidades serán procedentes en asuntos que se conocerán generalmente mediante el procedimiento abreviado o por órganos unipersonales. Ahora bien, como excepción, la Sala de lo contenciosoadministrativo del TSJ conocerá de los actos y resoluciones dictados por órganos de la Administración General del Estado cuya competencia se extienda a todo el territorio nacional y cuyo nivel orgánico sea inferior al de Ministro o Secretario de Estado en materias de personal, propiedades especiales y expropiación forzosa (art. 10.i LJCA). Asimismo, la Sala de lo contencioso-administrativo de la AN conocerá de los recursos contra los actos de cualesquiera órganos centrales del Ministerio de Defensa referidos a ascensos, orden y antigüedad en el escalafonamiento y destinos (art. 11.1.a LJCA). Y en tales casos, los supuestos anteriores también serán aplicables a pesar de no ventilarse los asuntos mediante el procedimiento abreviado ni tratarse de órganos unipersonales.

\section{Postulación facultativa y designación de domicilio en apela- ción (arts. 23.3 y 85.3 LJCA)}

La defensa técnica por abogado y la representación mediante procurador ha llegado a ser un presupuesto procesal precisamente en propio interés de la parte. Dado el carácter técnico-jurídico del instrumento

83 Ruiz: (n. 32), pp. 297-8. 
procesal y de la materia que se trata en el proceso, el interés de las partes y el del Estado en el correcto ejercicio de la potestad jurisdiccional han conducido, por regla general, a que los actos no los puedan realizar aquellas personas, sino unos técnicos en derecho que actúan por ellas. Se evita o reduce la posibilidad de que los actos sean afectados por vicios de ignorancia o error; y además concurre un interés público que se evidencia en la más fácil comunicación entre las partes y los tribunales, lo que implica una más fácil comprensión recíproca y se facilita la rapidez y seguridad de los actos procesales de comunicación $y$, por tanto, evita dilaciones ${ }^{84}$.

Así pues, la regla general de postulación en el proceso administrativo se encuentra en el art. 23 LJCA por el que "en sus actuaciones ante órganos unipersonales, las partes podrán conferir su representación a un Procurador y serán asistidas, en todo caso, por Abogado. Cuando las partes confieran su representación al Abogado, será a este a quien se notifiquen las actuaciones". Y a su vez, "en sus actuaciones ante órganos colegiados, las partes deberán conferir su representación a un Procurador y ser asistidas por Abogado".

Se distingue así entre órgano unipersonales, en que la representación mediante procurador será potestativa y preceptiva la asistencia de abogado, quien actuará como lo haría el procurador, es decir, también como representante a efectos de notificaciones; y entre órgano colegiados, en que será preceptiva tanto la representación mediante procurador como la asistencia técnica por abogado.

No obstante, se establece una importante excepción a la regla general primera en materia de funcionarios públicos y es que el mismo art. 23.3 LJCA dispone que "podrán, no obstante, comparecer por sí mismos los funcionarios públicos en defensa de sus derechos estatutarios, cuando se refieran a cuestiones de personal que no impliquen separación de empleados públicos inamovibles".

De ese modo, la postulación será en todo caso facultativa para los funcionarios, quienes podrán comparecer por sí mismos en defensa de sus derechos estatutarios, si bien solamente cuando la cuestión de personal no implique separación de empleados públicos inamovibles ${ }^{85} \mathrm{o}$, lo que viene a ser similar, siempre que no conozca órgano colegiado ${ }^{86}$.

84 Cfr. Ortells: (n. 25), pp. 132-3.

85 Dice la STS, Sala 3 $3^{\mathrm{a}}$, Secc. $7^{\mathrm{a}}, 24$ octubre 2003. RJ $2003 \backslash 7939$ que "consta que la Sra. Verónica tiene la calidad de funcionaria pública, y la materia en que se encuadra, lo que constituye el objeto del proceso, merece ser calificada como de personal, no afectante a la separación de empleados públicos inamovibles, por lo que resulta de aplicación el núm. 3 del art. 23 de la Ley de esta Jurisdicción, que autoriza, en tales casos a comparecer por sí mismos a los funcionarios en defensa de sus derechos". tación y defensa, se distingue entre órganos colegiados y unipersonales. En los primeros, procurador y 
A pesar de las dificultades prácticas que supone, tanto en cuanto al excesivo apasionamiento que puede implicar y la merma de técnica, sobre todo en lo que se refiere a las dificultades que plantea eventualmente en orden a la práctica de las notificaciones, esta excepción puede explicarse en que el legislador, en ejercicio de sus facultades, presupone que el funcionario es conocedor y técnico en la materia debatida ${ }^{87}$, también para evitar la disuasión que supone el coste de la representación y asistencia técnica cuando la cuantía es escasa, y en cierto modo igualmente en el principio de igualdad de los empleados públicos respecto del resto de trabajadores que, en virtud del art. 18.1 Ley de Procedimiento Laboral ${ }^{88}$, tienen la posibilidad de defender sus derechos legítimamente ante el orden social de la jurisdicción sin necesidad de postulación ${ }^{89}$. Así y todo, el mismo art. 23.3 LJCA impone limitaciones a esta postulación facultativa puesto que para ello exige que se trate de defensa de sus derechos estatutarios, esto es, los que le corresponde por su propia condición de funcionarios públicos y que se traten de materia de personal que no impliquen separación del servicio cuando se trate de empleados públicos inamovibles. Sin perjuicio de otras justificaciones que podamos encontrar ${ }^{90}$, se trata siempre de cuestión que quedará en

abogado son obligatorios; en los segundos, el procurador es potestativo y el abogado obligatorio. Los funcionarios públicos podrán comparecer por sí mismos en cuestiones de personal que no impliquen separación de empleados públicos inamovibles".

87 Garrido: (n, 27), p. 266. RuIz: (n. 32), p. 203.

88 Dispone que: "Las partes podrán comparecer por st mismas o conferir su representación al Procurador, Graduado Social colegiado o a cualquier persona que se encuentre en el pleno ejercicio de sus derechos civiles. La representación podrá conferirse mediante poder otorgado por comparecencia ante Secretario judicial o por escritura pública".

89 López-Medel Bascones, J. M., "Representación y defensa de las partes", en Vv. AA., Jurisdicción contencioso-administrativa (Comentarios a la Ley 29/1998, de 13 de julio, Reguladora de la Jurisdicción Contencioso-Administrativa), (Dirs.: Alnaldo Alcubilla y Fernández VAlverde), El Consultor, Madrid, 1998, pp. 526-7, quien además indica que previsiblemente también por presiones en el ámbito sindical. En sentido similar, con referencia al informe del CGPJ, Del Cacho Frago: (n, 49), pp. 86-7. Para Garberí llobregat, J., "Representación y defensa de las partes", en Vv. AA., Comentarios a la nueva Ley Reguladora de la Jurisdicción Contencioso-Administrativa de 1998 (con otros), Centro de Estudios Ramón Areces, S. A., Madrid, 1999, pág. 255, no goza de una sólida justificación material, sino que, por el contrario, obedece a un fenómeno de inercia histórica. Y siguiendo en esa línea, SaAvedra Gallo, P., "Nueva regulación de las partes", en Vv. AA., La nueva Ley de la Jurisdicción Contencioso-Administrativa. Estudio y aplicación práctica de la Ley 29/1998, (Dir.: GARBERí; coor.: MARTín), Colex, Madrid, 1999, p. 277, señala que este "privilegio" se mantiene sin razones ni motivos sólidos, señalando que su origen se remonta a cuando las cuestiones de personal eran resueltas por los órganos de la administración. La jurisprudencia ha desmentido el conocimiento de los funcionarios, no son posibles paralelismos con el proceso laboral.

90 Así, por ejemplo, Ruiz: (n. 32), pp. 203-4, entiende que la excepción parece lógica por la trascendencia de la materia, se justifica por la necesidad de especialización, y por conseguir la imprescindible objetividad en el planteamiento y/o tratamiento de la cuestión. Incluso podría explicarse pues en tal caso el funcionario carecería de su condición, sin perjuicio de las amplias posibilidades prácticas de suspensión del acto. 
el ámbito competencia de órgano colegiado, de modo que se ha limitado la excepción en el art. 23.3 LJCA a los órganos unipersonales en todo caso, quedando excluidos de los colegiados y, de ese modo, al menos a grandes rasgos, limitada al procedimiento abreviado.

La aplicación del art. 23.3 LJCA se preconiza de aplicación restrictiva. Así, además de la expresa exclusión de los supuestos que impliquen separación de empleado público inamovibles, ha de tratarse de funcionarios públicos, esto es, con estricta sujeción a su delimitación subjetiva en los términos de la Ley de Reforma de la Función Pública de 1984 y ha de ejercitarse en defensa de sus derechos estatutarios (nacimiento, contenido, esto es, derechos y deberes de la relación estatutaria y su extensión $)^{91}$.

Como consecuencia inmediata de esta postulación facultativa, a los efectos del recurso de apelación, el art. 85.3 LJCA prevé que "en los escritos de interposición del recurso y de oposición al mismo... los funcionarios públicos, en los procesos a que se refiere el artículo 23.3, designarán un domicilio para notificaciones en la sede de la Sala de lo Contencioso-Administrativo competente".

A pesar de las molestias que pueda suponer para el funcionario, esta previsión viene exigida por el interés público de, ante la ausencia de procurador o abogado que represente, facilitar los actos de comunicación $y$, por ende, evitar dilaciones indebidas como se ha señalado.

Con base probablemente en el interés privado y público al que se preordena la postulación así como a que las previsiones en el ámbito de los recursos se limitan a la apelación y por las propias características de otros recursos como el de queja y sobre todo el de casación ${ }^{92}$, la jurisprudencia ha venido considerando que será preceptiva para otros recursos (la súplica no es propiamente un recurso sino un remedio, en cuanto no tiene efecto devolutivo) como la casación y la queja ${ }^{93}$.

\footnotetext{
91 Álvarez-Cienfuegos: (n. 66), p. 100.
}

92 Del CaCho Frago: (n. 49), p. 87, afirman que "podría estudiarse que fuera preceptiva siempre la representación por Procurador y la asistencia de Abogado cuando se acuda al Tribunal Supremo, como ocurre cuando se comparece ante el Tribunal Constitucional. La complejidad técnica que, con carácter general, presentan los asuntos que se ventilan en la jurisdicción contencioso-administrativo aconsejan la asistencia de Letrado en los demás casos".

93 Respecto de la casación, como ejemplo entre la jurisprudencia más reciente, el ATS, Sala $3^{\mathrm{a}}$, Secc. $1^{\text {a }}, 29$ octubre 2001. RJ 2002/428, pone de manifiesto que: "en el artículo 90.1 de la nueva Ley no se haga mención expresa a la comparecencia de las partes mediante Procurador, a diferencia de lo que decía el artículo 97.1 de la Ley anterior, porque esa exigencia, y la consiguiente asistencia de Abogado, viene ahora establecida con carácter general en el articulo 23.2 de la vigente Ley (en sus actuaciones ante órganos colegiados, las partes deberán conferir su representación a un Procurador y ser asistidas por Abogado). Es cierto que, como excepción a las reglas generales en materia de postulación de los apartados 1 y 2 del artículo 23, el apartado 3 del mismo habilita a los funcionarios públicos para comparecer por sí mismos en defensa de sus derechos estatutarios, cuando se trate de cuestiones de 
Por último, ha de señalarse que en el caso de que, sin ser preceptivo, optara por acudir con abogado y procurador, la no preceptividad de la postulación no será óbice para que se le nombre abogado de oficio y ejercer, en su caso, el derecho a la asistencia jurídica gratuita que le corresponda. Ahora bien, no ha de olvidarse que la Ley 1/1996, de 10 enero 1996, regula la Asistencia Jurídica Gratuita, prevé en su art. 12 cómo ha de solicitarse este derecho ${ }^{94}$.

Partiendo de esta previsión, el Tribunal Supremo, concretamente su ATS, Sala $3^{\text {a }}$, Secc. $1^{\text {a }}, 1$ febrero 1999 , RJ 1999/2561, estima que no

personal que no impliquen separación de empleados públicos inamovibles, pero esta norma singular no es aplicable al recurso de casación. La postura patrocinada en el recurso de súplica descansa en una interpretación textual del artículo 23.3 difícilmente armonizable con el espiritu y finalidad de la norma contenida en su enunciado. La "ratio" de esta excepción, que no difiere esencialmente de la que introdujo el artículo 33.3 de la Ley de 1956, descansa en el conocimiento de la normativa aplicable al caso que se presume tienen los funcionarios públicos cuando están en litigio sus derechos estatutarios, pero esta consideración, a la que ya se refería la exposición de motivos de la citada Ley, pierde buena parte de su fuerza de convicción cuando del recurso de casación se trata. Se opone la complejidad de la actividad procesal, tanto en lo que bace a su contenido como a su forma, propia de este recurso extraordinario, que solo puede interponerse por determinados motivos, con el consiguiente rigor que este comporta en orden a la subsunción de los vicios jurídicos de que pueda adolecer la resolución judicial recurrida, pues no se debe olvidar que en el recurso de casación, a diferencia de lo que ocurren en la primera y segunda instancia, las pretensiones de las partes deben moverse en torno a la aplicación de la ley efectuada por el b́rgano jurisdiccional "a quo", quedando relegada a un segundo plano la actividad administrativa inicialmente impugnada, que es precisamente, en el caso de las cuestiones de personal, el dato del que arranca la presunción de que el funcionario público no está necesitado de asistencia jurídica. Y continúa diciendo el referido auto de 14 de febrero de 2000 en su Razonamiento Jurídico Segundo que "De lo anteriormente expuesto se desprende, que no obstante el silencio del artículo 90.1 de la vigente Ley Jurisdiccional la comparecencia ante esta Sala de los funcionarios públicos cuando la sentencia recurrida se refiere a cuestiones de personal debe bacerse por medio de Procurador y el escrito de interposición formularse además con la asistencia de Abogado, conclusión que queda reforzada si se repara en que el artículo 85.3, a propósito de la sustanciación del recurso de apelación, se obliga a los funcionarios públicos, en los procesos a que se refiere el artículo 23.3, a designar un domicilio para notificaciones en la Sala de lo contencioso-Administrativo competente para resolver el recurso, norma que, en cambio, no tiene su equivalente en el recurso de casación para la unificación de doctrina, a pesar de que también se sustancia, como el recurso de apelación, ante el órgano jurisdiccional "a quo". En el mismo sentido e incluso palabras, ATS, Sala $3^{a}$, Secc. $1^{\mathrm{a}}, 16$ julio 2001. RJ 2001/7880. Y lo mismo el ATS, Sala $3^{\mathrm{a}}$, Secc. $1^{\mathrm{a}}, 14$ febrero 2000. RJ 2000/1672, que añade, además, que "ningún quebranto se produce -al contrario-porque el recurrente deba estar representado por Procurador y asistido de Abogado para que pueda tenerse por válidamente formalizado el recurso de casación interpuesto, máxime cuando aquel señala en el recurso de súplica, a efectos de notificaciones, el domicilio de la Asesoría Jurídica Nacional del Sindicato CSI-CSIF". Y respecto del recurso de queja, en la misma línea, el ATS, Sala $3^{a}$, Secc. $1^{2}, 3$ julio 2000. RJ 2000/7219 dice que "como ya ba tenido ocasión de pronunciarse esta Sala en sus Autos de 14 de febrero y 10 de abril de 2000 (recursos 4995/1999 y 7503/1999), 5 de mayo de 2000 (recursos 229/2000 y 928/2000) y 22 de mayo de 2000 (recurso 7489/1999), a los que basta con remitirse, con arreglo a lo establecido en el artículo 23.2 de la Ley 29/1998, de 13 de julio, reguladora de la Jurisdicción Contencioso-Administrativa, la interposición ante esta Sala de un recurso de queja -incluidas las cuestiones de personal- debe realizarse mediante representación de Procurador y con asistencia de Letrado y sin que este pueda asumir aquella función".

94 Dispone este precepto que "el reconocimiento del derecho a la asistencia jurídica gratuita se instará por los solicitantes ante el Colegio de Abogados del lugar en que se balle el Juzgado o Tribunal que haya de conocer del proceso principal para el que aquel se solicita, o ante el Juzgado 
está habilitado para interesar nombramiento de Abogado y Procurador del turno de oficio 95 .

\section{Exclusión del recurso de casación (art. 86.2.a LJCA)}

Por último, a efecto de recurso de casación frente a sentencia dictada por la Sala de lo Contencioso-Administrativo de la Audiencia Nacional o de los Tribunales Superiores de Justicia, se excluye en las materia de personal que no "afecten al nacimiento o a la extinción de la relación de servicio de funcionarios de carrera" (art. 86.2.a LJCA) ${ }^{96}$.

Se excluye toda cuestión de personal, salvo que entren por la vía de la infracción de derechos fundamentales (art. 5.4 LOPJ), como el derecho de reunión o de huelga ${ }^{97}$, o a través de impugnación de resoluciones

de su domicilio. En este último caso, el órgano judicial dará traslado de la petición al Colegio de Abogados territorialmente competente. Cuando haya concurrencia de litigantes en un proceso, el reconocimiento del derecho a la asistencia jurídica gratuita deberá ser instado individualmente por cada uno de los interesados. Cuando con arreglo a las leyes procesales, los solicitantes deban litigar bajo una sola defensa o representación, deberán computarse, a efectos del reconocimiento del derecho, la totalidad de los ingresos y baberes patrimoniales de los solicitantes. En este caso, si se acreditara que los ingresos y haberes patrimoniales de cada uno de los solicitantes no sobrepasan el doble del salario mínimo interprofesional, se procederá a nombrar abogado y, en su caso, procurador del turno de oficio que deberán asumir la representación y defensa conjunta de todos ellos. Si se acreditara que los ingresos y haberes patrimoniales de cada uno de los solicitantes superan el doble del salario mínimo interprofesional pero no alcanzan el cuádruple, la Comisión de Asistencia Jurídica Gratuita podrá determinar cuáles de los beneficios establecidos en el artículo 6 se otorgará a los solicitantes".

95 Dice literalmente que "ni siquiera en el supuesto de insuficiencia económica sobrevenida del artículo 8 de la Ley 1/1996) -único en que es posible el reconocimiento del derecho a la asistencia jurídica gratuita una vez presentada la demanda-se encuentra babilitado este Tribunal para interesar el nombramiento de Abogado y Procurador del turno de oficio por estar sujeta dicha designación al régimen general de reconocimiento del derecho a la asistencia jurídica gratuita de que tratan los artículos 12 y concordantes de la Ley 1/1996".

96 Según la Exposición de motivos LJCA, VI, 3, párrafo primero, "de los recursos especiales se ba suprimido el de personal, aunque subsisten algunas especialidades relativas a esta materia a lo largo del articulado".

97 Mateo Díaz, J., "El recurso de casación ordinario", en La nueva Ley de la Jurisdicción Contencioso-Administrativa. Estudio y aplicación práctica de la Ley 29/1998, (Dir.: GARBERí; coor.: MARTín), Colex, Madrid, 1999, pp. 281-7. No obstante, parece que la doctrina jurisprudencial es bien distinta. Según el ATS, Sala 3a , Secc. 1a 5 febrero 2004, JUR 2004\142571, "tampoco pueden prosperar las alegaciones que se formulan en relación con el procedimiento especial de defensa de los derechos fundamentales, pues además de que dicho procedimiento no se ba seguido en el caso en examen, no cabe desconocer que la excepción prevista en el artículo 86.2.b), in fine, de la nueva LJCA -que abre el recurso de casación, cualquiera que sea la cuantía del asunto litigioso, respecto de las sentencias recaidas en dicho procedimiento especial- no es aplicable a las sentencias que se refieran a cuestiones de personal, como ya se ha dicho reiteradamente (asi Autos de 18 de octubre de 1999 -recursos núm. 1121/99 y 1351/99-, 28 de febrero de 2000 -recurso 4339/99-, 6 de octubre de 2000 -recurso núm. 1343/99- y 22 de enero de 2001 -recurso núm. 2861/99-, entre otros, a los que basta con remitirse) pues la contraexcepción del apartado b) del número 2 "in fine" del artículo 86 de la LJCA solo opera en los casos exceptuados del recurso de casación por razón de la cuantia, a lo que finalmente ba de añadirse que la invocación de lesión de derechos fundamentales no altera el régimen general de los recursos (por todos Autos de esta Sala de 13 de enero y 1 de julio de 1997), a salvo el supuesto del mencionado artículo 86.2.b), inciso final, de la nueva Ley". 
de contenido normativo en virtud del art. 93.3 LJCA, excepto la relativa a nacimiento o extinción de la relación de servicio de funcionarios de carrera. De ese modo se suaviza un tanto la exclusión general del art. 86.1 , si bien ha de tratarse de funcionarios de carrera, por lo que se excluye cualquier otra forma relación como la interinidad, contratados laborales, eventuales y hasta incluso los funcionarios en prácticas ${ }^{98}$. De esa manera se ha resuelto una vieja polémica planteada en la práctica.

No obstante, se crea un agravio comparativo respecto de los que no son funcionarios de carrera. Y si a ello añadimos la exclusión de materias del recurso de casación para la unificación de doctrina (art. 96.4, en relación con el art. 86.2.a.c y d, ambos LJCA), y las restricciones en la legitimación para interponer casación en interés de ley (art. 100 LJCA), se viene a impedir la unificación de doctrina en materia de personal salvo contadas excepciones: cuestiones relativas al nacimiento o extinción de la relación de servicio de los funcionarios de carrera, aparte de la casación de las disposiciones generales sea por recurso directo o indirecto (art. 86.3 LJCA) ${ }^{99}$. Con todo, la interpretación del art. 86 no ha de ser extensiva ${ }^{100}$.

La jurisprudencia del TS se ha pronunciado en reiteradas ocasiones en relación con el acceso a casación de las cuestiones de personal, entre las resoluciones más recientes, por ejemplo, la STS, Sala $3^{\mathrm{a}}$, Secc. $2^{\mathrm{a}}, 17$ octubre 2003, RJ 2003/8241 estima que no procede casación cuando la cuestión versa sobre un catálogo de puestos de trabajo. El ATS, Sala $3^{\mathrm{a}}$, Secc. $1^{\mathrm{a}}$, 15 enero 2001, RJ 2001/1390, entiende que a efectos de casación y tratándose de una cuestión de personal, no existe "diferencia alguna cuando el recurrente es una persona individualizada o un colectivo en defensa de unos derechos e intereses legítimos. Siendo irrelevante a estos efectos que la cuestión pueda afectar a las facultades organizativas de la Administración recurrente".

Igualmente ha señalado que la extinción ha de ser consecuencia de imposición administrativa, no cuando el funcionario pretende obtener

98 Sieira: (n. 13), pp. 929-30. Véase una síntesis de jurisprudencia en Mateo Díaz, J., "EI recurso de casación ordinario", en Vv. AA., La nueva Ley de la Jurisdicción Contencioso-Administrativa. Estudio y aplicación práctica de la Ley 29/1998, (Dir.: GARBERí; coor.: MARTíN), cit,, pp. 286-7. Véase igualmente, aunque sea en relación con la anterior LJCA, RosADO: (n. 8), pp. 88 y ss.

99 Cfr. CoRdón: (n. 39), p. 206.

100 Dice el ATS, Sala 3", Secc. 1", 15 enero 2001, RJ $2001 \backslash 1390$ que "como ya ba dicho esta Sala, la naturaleza extraordinaria del recurso de casación y su ámbito limitado no abonan interpretaciones extensivas a supuestos que no están estrictamente comprendidos en el marco que delimita el nuevo artículo 86 de la LJCA, siendo irrelevante, que el proceso se haya seguido en la instancia por los trámites del procedimiento ordinario, en lugar de bacerlo por el especial, pues en cuanto presupuesto procesal, la exclusión de las cuestiones de personal es materia de orden público cuyo examen y control corresponde inicialmente al Tribunal "a quo" y, en su caso, al Tribunal Supremo -artículo 93.2.a LJCA)-". 
la exclusión del servicio (ATS, Sala $3^{\text {a }}$, Secc. $1^{\text {a }}, 5$ febrero 2004, JUR 2004\142571). Y, también, en relación con el concepto de "funcionario de carrera", indica el mismo ATS, Sala $3^{\mathrm{a}}$, Secc. $1^{\mathrm{a}}$, 5 febrero 2004, que no lo ostentan los militares de empleo.

\section{Bibliografía CITADA}

- Alonso MÁs, $\mathrm{M}^{2}$. J., "Reflexiones sobre la nueva regulación de la extensión de los efectos de las sentencias", en Revista de Administración Pública, mayo-agosto 2004, pp. 271-308.

- Álvarez-Cienfuegos Suárez, J. M., y González Rivas, J. J., Análisis teórico y jurisprudencial de la Ley de la Jurisdicción Contencioso-Administrativa. Ley 29/1998, de 13 de julio, Aranzadi, Pamplona, 1998.

- Cordón Moreno, F., El proceso Contencioso Administrativo, Aranzadi, Pamplona, 1999.

- Del Cacho Frago, A., y Vacas García Alós, L., Comentarios a la Ley de la jurisdicción Contencioso-Administrativa, La Ley, Madrid, 1998.

- Fernández Valverde, F., "Del orden jurisdiccional contenciosoadministrativo", en Vv. AA., Jurisdicción contencioso-administrativa (Comentarios a la Ley 29/1998, de 13 de julio, Reguladora de la Jurisdicción Contencioso-Administrativa), (Dirs.: Alnaldo Alcubilla y FernánDeZ Valverde), El Consultor, Madrid, 1998, pp. 299-388.

- Garberí llobregat, J., "La competencia judicial en la nueva Ley", en Vv. AA., La nueva Ley de la Jurisdicción Contencioso-Administrativa. Estudio y aplicación práctica de la Ley 29/1998, (Dir.: Garberí; Coor.: Martín), Colex, Madrid, 1999, pp. 27-59.

- "Representación y defensa de las partes", en Vv. AA., Comentarios a la nueva Ley Reguladora de la Jurisdicción Contencioso-Administrativa de 1998 (con otros), Centro de Estudios Ramón Areces, S. A., Madrid, 1999, pp. 249-65.

- Garrido Falla, F., Tratado de Derecho Administrativo, III. La justicia administrativa (con otros), Tecnos, Madrid, 2001.

- GIl IbáÑeZ, J. L., "El nuevo procedimiento contencioso-administrativo abreviado", en Revista del Poder Judicial, núm. 53, 1999, pp. 269-307.

- Gimeno Sendra, V., Derecho Procesal Administrativo (con otros), Colex, $2^{a}$ ed., Madrid, 2004.

- González-Cuellar Serrano, N., "Sección 6a. Prueba", en Vv. AA., Comentarios a la nueva Ley Reguladora de la Jurisdicción Contencioso-Administrativa de 1998 (con otros), Centro de Estudios Ramón Areces, S. A., Madrid, 1999, pp. 449-83. 
- Linde Paniagua, E., "Luces y sombras en el procedimiento en primera o única instancia de la Ley de la Jurisdicción conteniosoadminsitrativa de 13 de julio de 1998", en Revista del Poder Judicial, núm. 56, 1999, pp. 273-95.

- López-Medel Bascones, J. M., "Representación y defensa de las partes", Jurisdicción contencioso-administrativa (Comentarios a la Ley 29/1998, de 13 de julio, Reguladora de la Jurisdicción ContenciosoAdministrativa) (Dirs.: Alnaldo Alcubilla y Fernández ValVERDE), El Consultor, Madrid, 1998, pp. 523-37.

- Mateo Díaz, J., "El recurso de casación ordinario", en Vv. AA., La nueva Ley de la Jurisdicción Contencioso-Administrativa. Estudio y aplicación práctica de la Ley 29/1998, (Dir.: GARBERÍ; Coor.: MARTíN), Colex, Madrid, 1999, pp. 281-307.

- Martín Contreras, L., La extensión de efectos de las sentencias en la jurisdicción contencioso-administrativa en materia tributaria y de personal, Comares, Granada, 2000.

- Milans del Bosch y Jordán de Urríes, S., "Órganos y competencias", en Vv. AA., Jurisdicción contencioso-administrativa (Comentarios a la Ley 29/1998, de 13 de julio, Reguladora de la Jurisdicción Contencioso-Administrativa), (Dirs.: Alnaldo Alcubilla y FernánDeZ VAlverde), El Consultor, Madrid, 1998, pp. 389-456.

- Moreno Catena, V., Derecho Procesal Administrativo (con otros), Colex, $2^{a}$ ed., Madrid, 2004.

- Moscoso Torres, P. J., "El recurso contencioso-administrativo (II): Innovaciones procedimentales (acumulación, prueba y sentencia)", en Vv. AA., La nueva Ley de la Jurisdicción Contencioso-Administrativa. Estudio y aplicación práctica de la Ley 29/1998, (Dir.: Garberí; Coor.: Martín), Colex, Madrid, 1999, pp. 233-53.

- Ortells Ramos, M., Derecho Procesal Civil (con otros), ThomsonAranzadi, $5^{a}$ ed., Cizur Menor, 2004.

- Pemán Gavín, J., "Sobre la nueva regulación de la jurisdicción contencioso-administrativa: las novedades relativas al objeto y las partes y al objeto del proceso", en Revista del Poder Judicial, núm. 54, 1999, pp. 401-48.

- Robles Garzón, J. A., "Los recursos en la nueva Ley de la Jurisdicción Contencioso-Administrativa", en Revista del Poder Judicial, núm. 58, 2000, pp. 369-422.

- Rosado Pacheco, S., El proceso de personal en la jurisdicción contencioso-administrativa, Marcial Pons, Madrid, 1977.

- Ruiz Risueño, F., El proceso contencioso-administrativo. Ley 29/1998, de 13 de julio, Reguladora de la Jurisdicción Contencioso-Administrativa, Colex, $5^{a}$ ed., Madrid, 2004.

- SaAvedra Gallo, P., "Nueva regulación de las partes", en Vv. Aa., La nueva Ley de la Jurisdicción Contencioso-Administrativa. Estudio y 
aplicación práctica de la Ley 29/1998, (Dir.: GARBERí; Coor.: MARTín), Colex, Madrid, 1999, pp. 273-80.

- Sainz Moreno, F., "El procedimiento abreviado", en Vv. Aa., Comentarios a la Ley de la Jurisdicción contencioso-administrativa, (Dirs.: Leguina Villa y Sánchez Morón), Lex Nova, Valladolid, 1999, pp. 361-77.

- Sala Sánchez, P., Derecho Procesal Administrativo (con otros), Colex, $2^{\mathrm{a}}$ ed., Madrid, 2004.

- Sieira Míguez, J. M., "Recurso de casación", en Vv. AA., Jurisdicción contencioso-administrativa (Comentarios a la Ley 29/1998, de 13 de julio, Reguladora de la Jurisdicción Contencioso-Administrativa), (Dirs.: Alnaldo Alcubilla y Fernández Valverde), El Consultor, Madrid, 1998, pp. 923-1131.

- Téllez Aguilera, A., El procedimiento contencioso-administrativo abreviado, Edisofer, Madrid, 2000.

- VV.AA., Jurisdicción contencioso-administrativa (Comentarios a la Ley 29/1998, de 13 de julio, Reguladora de la Jurisdicción Contencioso-Administrativa), (Dirs.: Alnaldo Alcubilla y Fernández ValverDE), El Consultor, Madrid, 1998.

- VV.AA., Comentarios a la Ley de la Jurisdicción contencioso-administrativa, (Dirs.: Leguina Villa y SánChez Morón), El Lex Nova, Valladolid, 1999.

- VV.AA., La nueva Ley de la Jurisdicción Contencioso-Administrativa. Estudio y aplicación práctica de la Ley 29/1998, (Dir.: GARBERÍ; Coor.: MARTín), Colex, Madrid, 1999.

- VV.AA., Comentarios a la nueva Ley Reguladora de la Jurisdicción Contencioso-Administrativa de 1998, Centro de Estudios Ramón Areces, S. A., Madrid, 1999. 